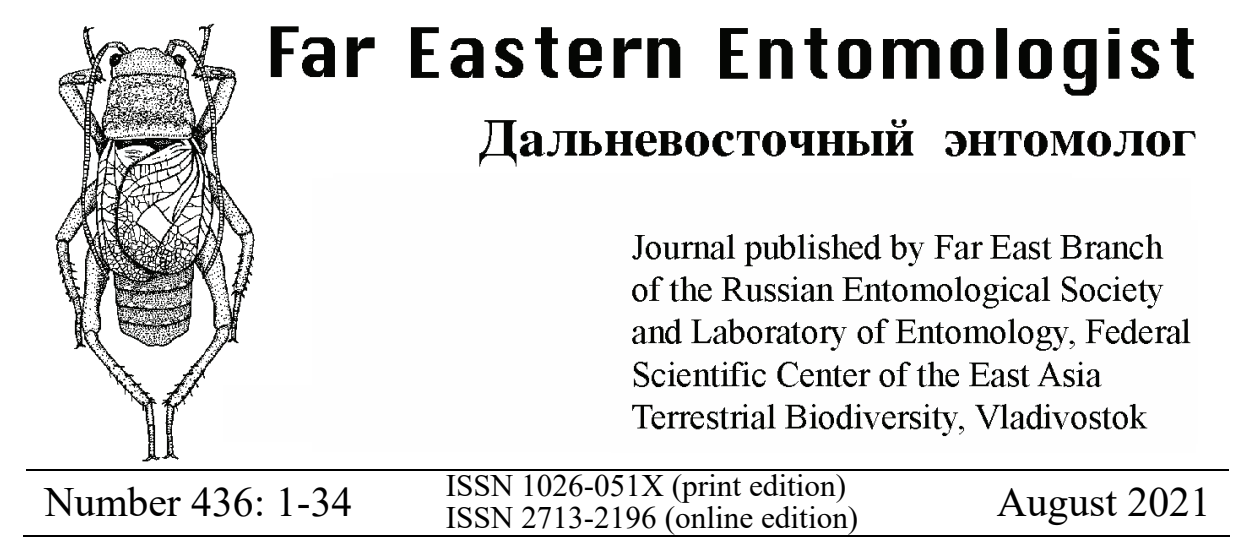

https://doi.org/10.25221/fee.436.1

http://zoobank.org/References/15B64701-B2F9-4097-AE2A-A1EE04082C48

\title{
REVIEW OF THE SUBTRIBE PSILOMMINA (HYMENOPTERA: DIAPRIIDAE, BELYTINAE) FROM RUSSIAN FAUNA
}

\author{
V. G. Chemyreva ${ }^{1, *)}$, V. A. Kolyada ${ }^{2)}$
}

1) Zoological Institute, Russian Academy of Sciences, St. Petersburg, 199034 Russia.*Corresponding author, E-mail: diapriidas.vas@gmail.com

2) Palaeontological Institute, Russian Academy of Sciences, Moscow, 117997 Russia.

Summary. Three species of the Acanopsilus Kieffer, 1908, six species of Acanosema Kieffer, 1908, two species of Polypeza Förster, 1856, and four species of Psilomma Förster, 1856 of the Russian fauna are reviewed, keyed and illustrated. Six of these species are described: Acanopsilus comadensis sp. n. (Russia: Primorsky krai), A. minimus sp. n. (Russia: Primorsky krai), Acanosema (Cardiopsilus) dentigastrum sp. n. (Russia: Primorsky krai), A. (C.) epicnemium sp. n. (Russia: Primorsky krai) A. (C.) setigerum sp. n. (Russia: East Siberia, Yakutia; Sweden), Psilomma calaris sp. n. (Russia: Kunashir Island; Japan). The generic status of Cardiopsilus Kieffer, 1908 is reduced to subgeneric one under Acanosema Kieffer, 1908 and a new combination is proposed for A. productum (Kieffer, 1908), comb. n. from Cardiopsilus Kieffer, 1908.

Key words: Pantolytini, taxonomy, new species, new combinations, fauna, new records, key, Russia.

В. Г. Чемырева, В. А. Коляда. Обзор подтрибы Psilommina (Hymenoptera: Diapriidae, Belytinae) фауны России // Дальневосточный энтомолог. 2021. N 436. C. 1-34. 
Резюме. Дан обзор, определительные таблицы и иллюстрации трех видов Acanopsilus Kieffer, 1908, шести видов Acanosema Kieffer, 1908, двух видов рода Polypeza Förster, 1856 и четырех видов рода Psilomma Förster, 1856 фауны России. Шесть из этих видов описываются как новые: Acanopsilus comadensis sp. n. (Россия: Приморский край), A. minimus sp. n. (Россия: Приморский край), Acanosema (Cardiopsilus) dentigastrum sp. n. (Россия: Приморский край), $A$. $(C$.) epicnemium sp. n. (Россия: Приморский край) $A$. (C.) setigerum sp. n. (Россия: Восточная Сибирь, Якутия; Швеция), Psilomma calaris sp. n. (Россия: о-в Кунашир; Япония). Статус рода Cardiopsilus Kieffer, 1908 понижен до подрода в Acanosema Kieffer, 1908 и предлагается новая комбинация для $A$. productum (Kieffer, 1908), comb. п. из Cardiopsilus Kieffer, 1908.

\section{INTRODUCTION}

This research is the last one of a series about the Russian species of the tribe Pantolytini (Chemyreva \& Kolyada, 2019, 2020, 2021; Chemyreva, 2021) and it almost repeats the similar treatise devoted to European Psilommina (Macek, 1990). The aim of this study is reviewing of the genera Psilommina subtribe. The subtribe Psilommina has been proposed by Macek (1989) for the six genera. The genus Synacra Förster was reviewed in Russia earlier (Chemyreva \& Kolyada, 2019). In this research four genera with 15 species are reviewed for the Russian fauna.

The European species of the genera Acanopsilus Kieffer, Acanosema Kieffer, Cardiopsilus Kieffer, Psilommacra Macek [these genera were united by Macek (1990) into Acanosema complex] as well as Psilomma Förster and Polypeza Förster, were revised by Macek (1990, 1993). According to his revisions only one species from the genera Acanopsilus, Cardiopsilus, Psilommacra and Polypeza, and three species of both genera Psilomma and Acanosema were known from Europe. Only two species: Acanosema nervosum Kieffer and Polypeza ciliata (Thomson) were known from Russian fauna from the European part and Eastern Siberia respectively (Kozlov, 1978).

The biology of these species is poorly known. Nixon (1957) has noticed Acanosema rufum Kieffer from the nest of the ant Lasius brunneus (Latreille) and saprophagous larvae of Sciaridae and Mycetophilidae living in rotten wood have reported as host of Acanosema nervosum.

\section{MATERIALS AND METHODS}

This study is based on examination of the material from collections of the Zoological Institute of the Russian Academy of Sciences (St. Petersburg, Russia; ZISP), the Zoological Museum of the Moscow State University, Moscow, Russia (ZMUM), the National History Museum, University of Tartu, Tartu, Estonia (TUZ), the Kanagawa Prefectural Museum of Natural History, Odawara, Japan (KPMNH), and comprehensive material from the collection of J. Macek in the National Museum Prague, Prague, Czech Republic (NMPC).

Material for this study was collected in various parts of Russia and several neighboring countries by yellow pan traps, Malaise traps, flight intercept traps or net sweeping. 
Morphological terminology and abbreviations follow Naumann (1982), Masner \& García (2002), Yoder (2004), Yoder et al. (2010). Measurements mostly follow Yoder (2004), Chemyreva \& Kolyada (2019). Morphological terminologies of some mesopleural structures see Fig. 1. Generic and species synonyms follow to Macek (1990, 1993).

New records are asterisked $(*)$.The following abbreviations are used in the text: A1-A13 - antennomeres; T, S - metasomal terga and sterna respectively. The general distribution of species follows Macek (1990), Kim \& Lee (2016a, b). The species of the Psilommina subtribe can be identified by using the subtribe diagnosis (Macek, 1989). The generic affiliation of the Psilommina species can be recognized using the generic key given by Macek (1989).

All photographs were obtained using a Leica M165 stereomicroscope equipped with a Leica DFC450 camera. Image stacking was performed with Helicon Focus 5.0.

TAXONOMY

Family Diapriidae Haliday, 1833

Subfamily Belytinae Förster, 1856

Tribe Pantolytini Hellén, 1963

Subtribe Psilommina Macek, 1989

Acanopsilus Kieffer, 1908: 426.

Genus Acanopsilus Kieffer, 1908

Type species: Acanopsilus clavatus Kieffer, 1908 (=Belyta heterocera Haliday, 1857), by monotypy.

REMARKS. A single species from the genus Psilommacra Macek, 1990 is still not found in Russia. We have studied a male from Ukraine and paratypes from Czech Republic. It is hardly to distinguish the males of P. olygomera Macek, 1990 from the males of Acanopsilus species and the both genera are very close. Since the discovery of the species is possible in Russia we include this species of Psilommacra in the key below.

\section{Key to species of the genera Acanopsilus and Psilommacra}

\section{Female}

1. Antenna 13-segmented

P. olygomera Macek

Antenna 14-segmented

2. Eye pubescent; marginal vein as long as distance from it to basal vein; base of T2 with a few long setae laterally (Fig. 24); pubescence of pronotal pit weak (Fig. 4)

A. minimus sp. $\mathrm{n}$.

- Eye bare; marginal vein shorter than distance from it to basal vein; base of T2 with dense bunch of setae laterally (Figs 7, 14); pubescence of pronotal pit dense (Figs 1, 3) ......... 3

3. Mesopleuron above epicnemial pit pubescent (Fig. 3); occipital flange medially pubescent (Fig. 9) A. comadensis sp. $\mathbf{n}$.

- Mesopleuron above epicnemial pit bare (Fig. 1); occipital flange medially bare (Fig. 13) A. heterocerus (Haliday) 


\section{Male}

1. Eye bare; marginal vein distinctly shorter than distance from it to basal vein; base of T2 with dense bunch of setae laterally (Figs 7, 14)

- Eye pubescent; marginal vein as long as distance from it to basal vein; base of T2 with a few long setae laterally (Fig. 24)

2. Mesopleuron above epicnemial pit densely pubescent (Fig. 3); occipital flange medially pubescent (Fig. 9) A. comadensis sp. n.

- Mesopleuron above epicnemial pit bare (Fig. 1); occipital flange medially bare (Fig. 13) A. heterocerus (Haliday)

3. Medial keel of propodeum bifurcate from its base (Fig. 24); subalar bridge on mesopleuron absent (Fig. 4); pronotal pit with few scattered setae inside (Fig. 4) ..... A. minimus sp. n.

- Medial keel of propodeum simple; subalar bridge on mesopleuron distinct; pronotal pit with dense pubescence P. olygomera Macek

\section{Acanopsilus comadensis Chemyreva et Kolyada, sp. $\mathbf{n}$.}

http://zoobank.org/NomenclaturalActs/9CEE159A-DE72-4377-B4BF-6F7826AAB7F8

Figs 3, 5-11

TYPE MATERIAL. Holotype - 9 , Russia: Primorsky krai, $20 \mathrm{~km}$ SE of Ussuriysk, Gornotayozhnoe, 31.VII-5.VIII 1991, S. Belokobylskij (ZISP). Paratypes Russia: same label as holotype, 1 ô; Primorsky krai, Novonezhinskiy Distr., Kangauz [Anisimovka], 18.VIII 1972, 2 ㅇ, V. Kuslitzky; Vladivostok City, 1921.VIII 1972, 1 , , V. Kuslitzky (all in ZISP).

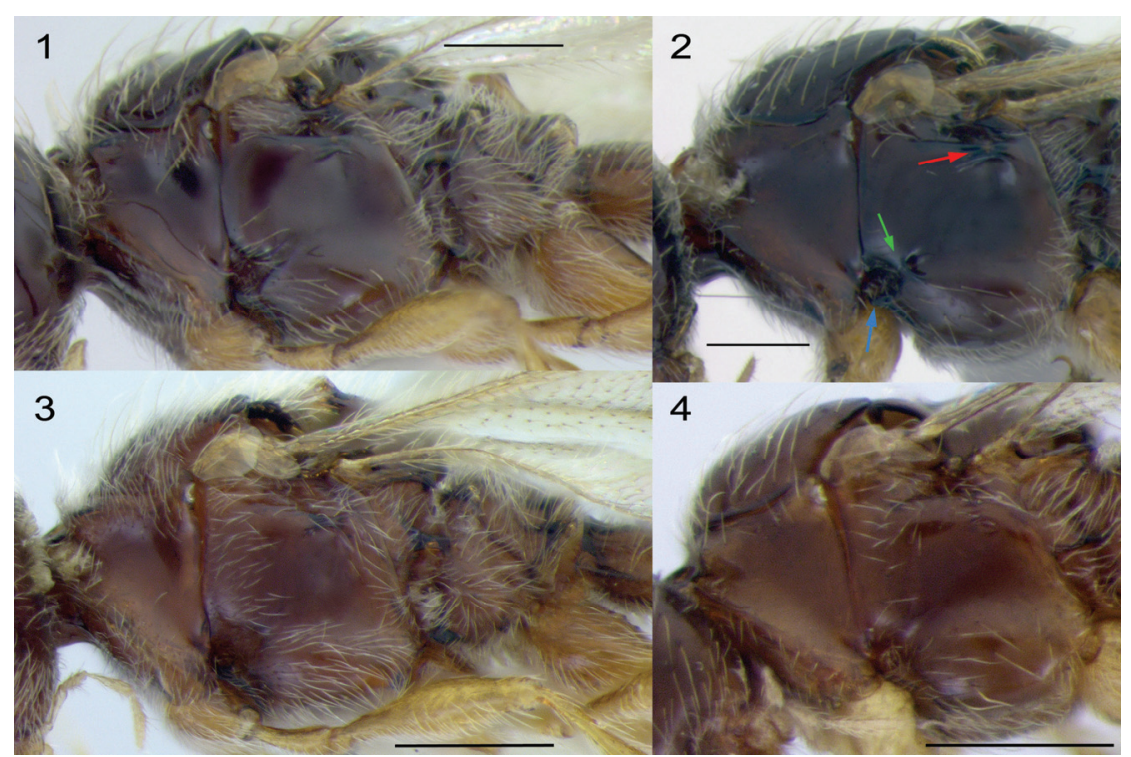

Figs 1-4. Mesosoma, lateral view: 1 - Acanopsilus heterocerus; 2 - Acanosema nervosum; 3 - Acanopsilus comadensis sp. n.; 4 - Acanopsilus minimus sp. n.; red arrow - subalar bridge; green arrow - epicnemial bridge; blue arrow - epicnemial pit. Scale bar $0.2 \mathrm{~mm}$. 
DESCRIPTION. Female. Body length $2.5 \mathrm{~mm}$; fore wing length $2.1 \mathrm{~mm}$; antennae length $1.6 \mathrm{~mm}$.

Color. Head and mesosoma dark brown, metasoma reddish brown, A13-A14, mesosoma and petiole dark brown; palpi, legs, tegulae, proximal half of antennae and venation pale brown; distal half of antennae and mandibles brown.

Head in dorsal view nasiform, 1.1 times as long as wide, wider than mesosoma (23:20), smooth and densely pubescent (Fig. 9). Temples gradually receding behind eye. Occipital flange very narrow and densely pubescent. Head in lateral view as long as high. Eyes bare, its largest diameter shorter than malar space (7:8). Antennal shelf in front view with coriaceous sculpture below toruli. Face smooth. Head in front view with mouth conus (Fig. 6). Clypeus transverse, 0.8 times as high as wide. Tentorial pits small. Labrum small, semicircular, weakly visible. Mandibles simple.

Antennae slender, weakly broadened apically. A1 0.86 times as long as width of head. Ratios of length to width of A1-A14 shown on Fig. 10.

Mesosoma weakly compressed, slightly higher than wide (10:9). Neck and pronotal collar situated almost in same plane (Fig. 3). Pronotal anterior corners sharped, epomia strongly prominent and interrupt by pronotal pits. Pronotal collar, corners and pits pubescent; neck dorsally and sides of pronotum mainly bare. Mesoscutum 0.77 times as long as wide, convex, pubescent with semi-erect setae. Notauli deep and complete throughout. Anterior scutellar pit deep, large, bare and rounded. Scutellum large, convex, widened posteriorly. Axillar depression without verriculate tubercles. Mesopleuron bare medially and pubescent elsewhere, with subalar bridge postero-dorsally and without epicnemial bridge antero-ventrally; epicnemial pit deep and densely pubescent; mesopleural pit totally absent (Fig. 3). Metanotum narrow, with smooth and bare lateral sides and pubescent metascutellum; metascutellum with three short longitudinal keels, median keel the highest. Propodeum transverse, 0.64 times as long as wide, weakly pubescent, median propodeal keel simple, plicae process complete (Fig. 7). Side of propodeum densely pubescent, with two longitudinal keels (Fig. 3). Legs slender.

Wing venation. Fore wing with distinct costal and subcostal veins; radial cell open; basal vein distinct but paler than subcosta; distance from marginal vein to basal vein longer than marginal vein length (14:12); stigmal vein as long as wide of marginal vein (Fig. 8). Poststigmal, postmarginal and radial veins absent.

Metasoma. Petiole cylindrical, 1.25 times as long as wide, with longitudinal keels, bare dorsally and densely pubescent laterally and ventrally; posterior margin of petiole weakly arcuate (Fig. 7). T2 anteriorly with short striation similar in length; T3-T6 narrow, with few setae laterally and fine micropunctation medially; T7 and T8 elongate, compressed laterally. S2 without protuberans anteriorly; with short grooves and dense pubescent at base and numerous setae posteriorly; S3-S5 narrow, with scattered long setae; S6 entirely pubescent, distinctly elongate and compressed.

Male. Body length $2.3 \mathrm{~mm}$. Similar to female except following characters: antenna filiform, longer than body length; antennomeres cylindrical, covered by uniform semi-erect pubescence; A1 slender, 0.63 times as long as width of head; A3 with shallow emargination, with keel extending almost half of $\mathrm{A} 3$ length; ratios of length 
to width of A1-A14 shown on Fig. 11; petiole more elongate 0.4 times as wide as long; metasoma not compressed at top; T7 transverse; T8 and S8 subtriangular, rounded apically; S2-S7 with numerous semi-recumbent scattered setae; S8 finely pubescent.

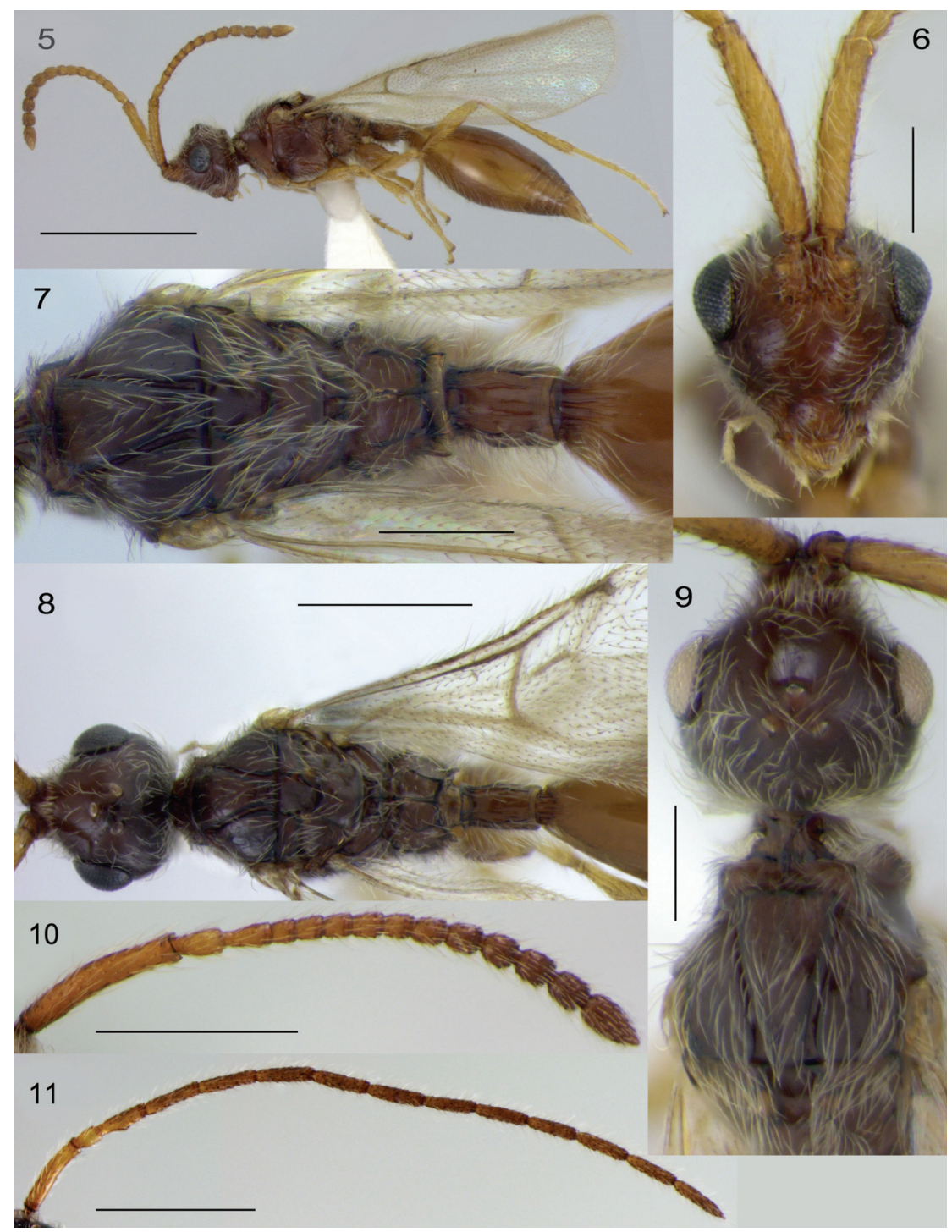

Figs 5-11. Acanopsilus comadensis sp. n., 우 $(5-7,9,10)$ and $\lesssim(8,11): 5$ - habitus, lateral view; 6 - face; 7 - mesosoma and base of metasoma, dorsal view; 8 - body and forewing venation, dorsal view; 9 - head and mesosoma, dorsal view; 10, 11 - antennae. Scale bar: $5-1 \mathrm{~mm} ; 8,10,11-0.5 \mathrm{~mm} ; 6,7,9-0.2 \mathrm{~mm}$. 
VARIATION. Female. Body length 2.5-3.0. Significant variation is not detected.

DIAGNOSIS. This species distinctly differs from all other Acanopsilus species by the combination of the following characters: medium size, brunneous species; head and mesosoma densely pubescent (occipital flange medially, mesopleuron above epicnemial pit and base of T2 pubescent); eyes bare; marginal vein distinctly shorter than distance from it to basal vein; S2 without protuberans anteriorly.

DISTRIBUTION. Russia (Far East).

ETYMOLOGY. The name is derived from the Latin noun coma (hear) and an adjective densa (dense) and refers to the dense pubescence of head and mesosoma that is typical for this new species.

\section{Acanopsilus heterocerus (Haliday, 1857)}

Figs 1, 12-17

Belyta heterocera Haliday, 1857: 169.

MATERIAL. Ukraine: Zakarpatska Prov., Karpatskiy Nature Reserve, Manchul Mt. 1400 m, 8.VIII 1989, 4 ふ̃, A. Kotenko; Russia: Republic of Crimea: Karadag Mt., 9.VI.1990, 1 ㅇ, A. Kotenko; Kara-Dag N.R., 21-27.IX 1996, 4 ․, D. Kasparyan; Kara-Dag N.R., 24-27.VII 1996, 1 +, V. Kolyada; Yalta, Nikitsky Botanical Garden, 31.V 1995, 3 ㅇ, V. Kolyada; Krasnodarsky krai: Sochi City, Lazorevskoe, 20-24.V 1973, 1 ते, V. Tobias; Kirovskaya oblast: Bolsheromanovo, 4-7.VIII

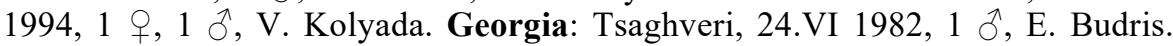
Azerbaijan: Hirkan National park, 16.VI 2009, 1 त, K. Tomkovich. Turkmenistan: canyon Aydere, 9.V 1980, 2 ठิ, N. Storozheva. Uzbekistan: KyzylKum, Aktau Ridge, 22.V 1963, 3 9, I. Kerzhner.

VARIATION. Both sex: marginal vein 5-7 times longer than its width and 0.60.9 times as long as distance from it to basal vein. Female: body length 3.0-3.4; petiole cylindrical and elongate (about 0.7 times as wide as long) to weakly widened posteriorly and as wide as long; S2 distinctly to weakly swollen at base. Male: body length 2.8-3.4; A4 with keel extending to $0.3-0.5$ of this segment length.

DISTRIBUTION. United Kingdom, Sweden, Germany, Italy, Czech Republic, Austria, Hungary, Greece, Ukraine, *Russia (European part), *Georgia, *Azerbaijan, *Turkmenistan, *Uzbekistan, China, South Korea.

\section{Acanopsilus minimus Chemyreva et Kolyada, sp. n.}

http://zoobank.org/NomenclaturalActs/97B58500-1080-4E38-89A9-33659AC69867

Figs 4, 18-24

TYPE MATERIAL. Holotype - + , Russia, Primorsky krai, near Spassk-Dalniy, 6-10.IX 2001, S. Belokobylskij (ZISP). Paratypes - Russia. Sakhalinskaya oblast: Kunashir Island, 22.VIII-1.IX 1973, 1 ô, D. Kasparyan; Primorsky krai: Lazo Nature Reserve, 18 km SE of Lazo, 26.VIII 2006, 1 ㅇ, S. Belokobylskij; near SpasskDalniy, 26.VI-5.VII 2007, 1 đ̃, S. Belokobylskij; Shkotovskiy Distr., Peyshula,

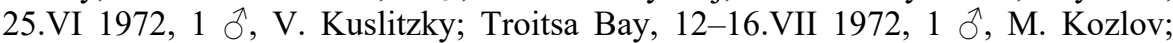
Tachingouza Bay [Lazo Nature Reserve], 9-10.VIII 1972, 1 ㅇ, M. Kozlov (all in ZISP). 
DESCRIPTION. Female. Body length $2.1 \mathrm{~mm}$; fore wing length $2.0 \mathrm{~mm}$; antennae length $1.4 \mathrm{~mm}$.

Color. Entirely body and A3-A14 brown; venation and tegulae pale brown; mandibles, palpi, A1-A2, and legs yellow.

Head in dorsal view not nasiform, 0.9 times as long as wide, wider than mesosoma (30:28), smooth and covered by long scattered setae (Fig. 18). Temples gradually receding behind eye. Occipital flange very narrow, smooth. Head in lateral view slightly

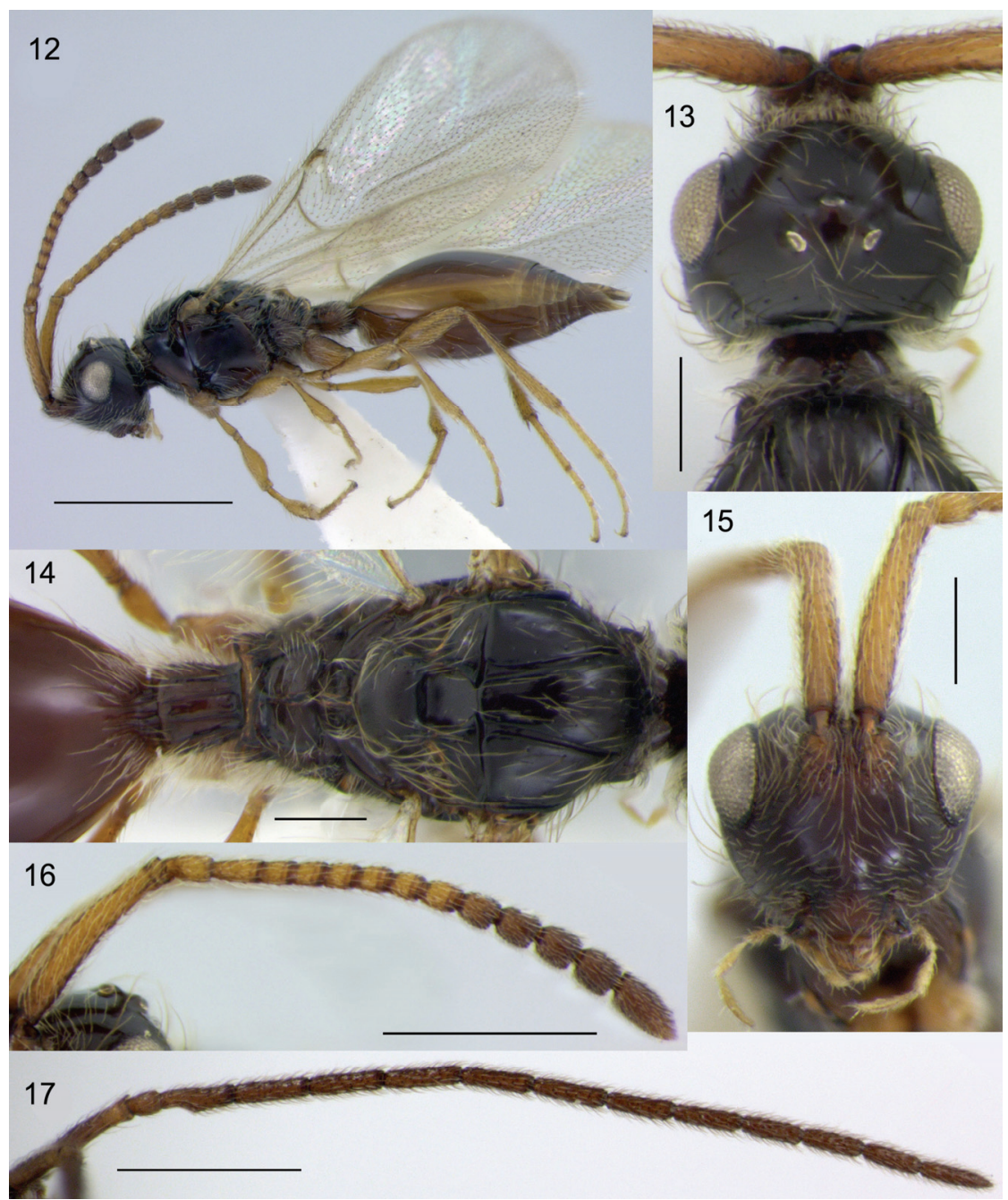

Figs 12-17. Acanopsilus heterocerus, $\bigcirc$ (12-16) and $\hat{\circ}(17): 12$ - habitus, lateral view; 13 - head, dorsal view; 14 - mesosoma and base of metasoma, dorsal view; 15 - face; 16, 17 - antennae. Scale bar: $12-1 \mathrm{~mm} ; 16,17-0.5 \mathrm{~mm} ; 13-15-0.2 \mathrm{~mm}$. 
higher than length (14:15). Eyes setose, its largest diameter as long as malar space. Antennal shelf in front view smooth. Face smooth. Head in front view with mouth conus (Fig. 19). Clypeus 0.71 times as high as wide. Tentorial pits large. Labrum small, semicircular, distinctly visible. Mandibles simple.

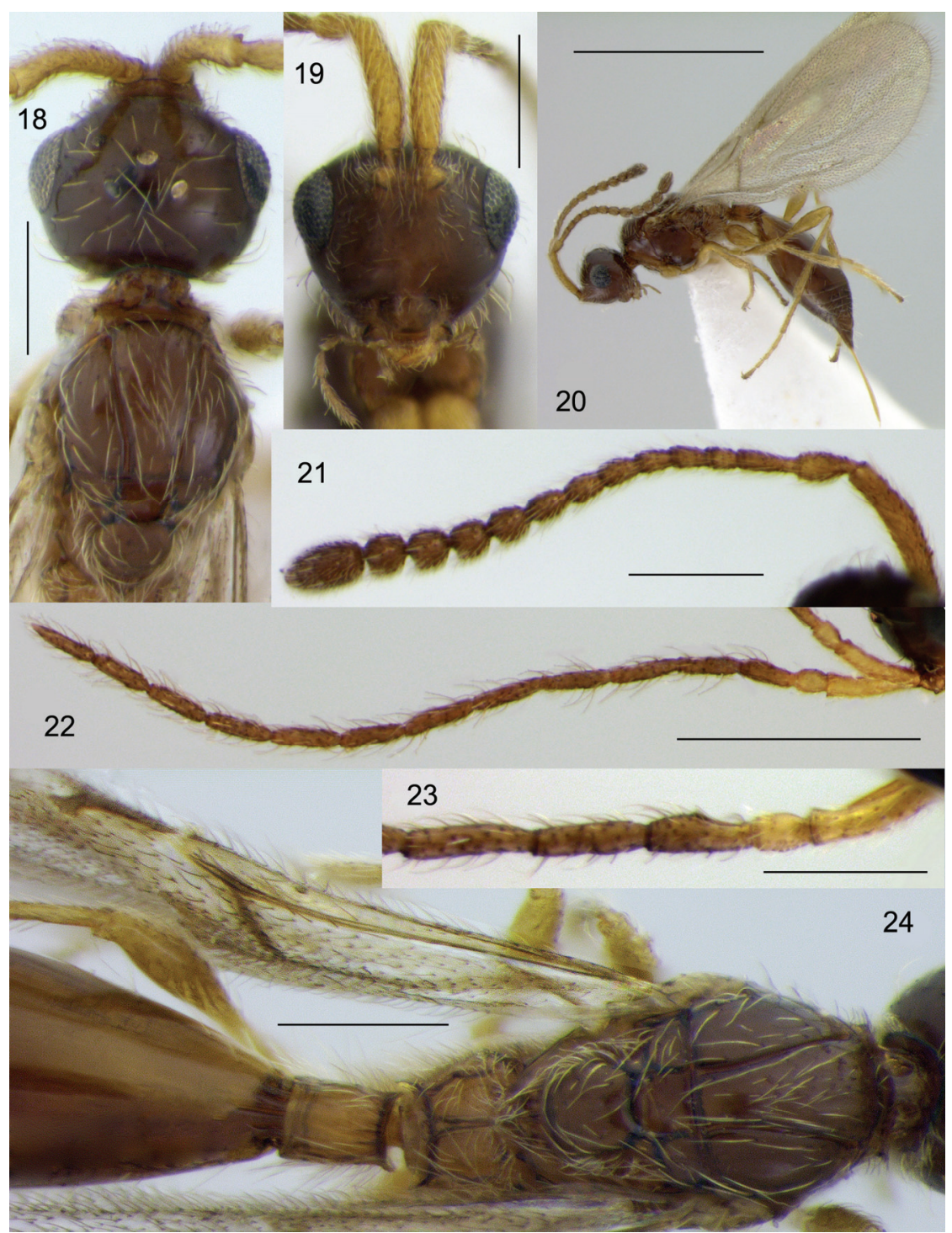

Figs 18-24. Acanopsilus minimus sp. n., $\subsetneq(18-21,24)$ and $\hat{\partial}(22,23): 18$ - head and mesosoma, dorsal view; 19 - face; 20 - habitus, lateral view; 21, 22 - antennae; 23 - antenna, proximal part; 24 - mesosoma, proximal part of metasoma and forewing venation, dorsal view. Scale bar: $20-1 \mathrm{~mm} ; 22-0.5 \mathrm{~mm} ; 18,19,21,23,24-0.2 \mathrm{~mm}$. 
Antennae slender, weakly broadened apically. A1 0.84 times as long as width of head. Ratios of length to width of A1-A14 shown on Fig. 21.

Mesosoma slightly compressed, slightly higher than wide (33:26). Neck and pronotal collar situated perpendicularly to each other (Fig. 4). Pronotal anterior corners weakly prominent, sharped. Pronotal collar, corners and pronotal pits covered by scattered long setae; neck dorsally and sides of pronotum bare. Mesoscutum 0.8 times as long as wide, convex, covered by scattered long setae. Notauli deep and complete throughout. Anterior scutellar pit deep, large, bare and rounded. Scutellum large, convex, widened posteriorly. Axillar depression without verriculate tubercles. Mesopleuron mainly bare, with subalar bridge postero-dorsally and without epicnemial bridge antero-ventrally; epicnemial pit deep and weakly pubescent; mesopleural pit totally absent (Fig. 4). Metanotum narrow, with smooth and bare lateral sides and pubescent metascutellum; metascutellum with three short longitudinal keels, median keel the highest. Propodeum 0.53 times as long as wide, sparsely pubescent posteriorly and more dense anteriorly, median propodeal keel bifurcate from base, plicae process complete (Fig. 24). Side of propodeum entirely finely pubescent, with two longitudinal keels. Legs slender.

Wing venation. Fore wing with distinct costal, subcostal and basal veins; radial cell open; marginal vein longer than distance from it to basal vein (11:9); marginal vein 5 times longer than its wide; stigmal vein twice as long as wide of marginal vein (Fig. 24). Poststigmal vein absent. Postmarginal vein nebulous. Radial vein as long as stigma vein.

Metasoma. Petiole cylindrical, elongate 0.73 times as wide as long, with traces of longitudinal keels, bare dorsally and densely pubescent laterally and ventrally; posterior margin of petiole not arcuate. T2 anteriorly with short grooves, the medial slightly longer than others (Fig. 24); T3-T6 narrow, with few setae and fine micropunctation medially and numerous setae laterally; T7 and T8 elongate, compressed laterally, pubescent. S2 without protuberance anteriorly, with short grooves and dense pubescent at base and almost bare posteriorly; S3-S5 narrow, with numerous long setae; S6 pubescent, distinctly elongate and compressed.

Male. Body length 1.6-1.9 mm. Similar to female except following characters: antenna filiform, slightly longer than body length; antennomeres cylindrical, covered by long (about 1.3 times longer than width of appropriate antennomer) semi-erect setae; A1 stout, about 0.5 times as long as width of head; A3 with shallow emargination and keel extending to half of A3 length; ratios of length to width of A1-A14 shown on Fig. 22; petiole weakly more elongate $0.60-0.65$ times as wide as long; metasoma not compressed at top; T7 transverse; T8 and S8 semi-circular; S2-S7 with numerous semi-recumbent scattered setae; S8 finely pubescent.

VARIATION. Female. Body length 1.8-2.1. Significant variation is not detected.

DIAGNOSIS. This species distinctly differs from all other Acanopsilus species by the combination of the following characters: small (1.6-2.1), brunneous and sparsely hairy species; eyes setose; A1 with simple apical rim; pronotal pit weakly setose; mesopleuron with subalar bridge and without epicnemial bridge; median propodeal keel bifurcate from base; marginal vein as long as distance from it to basal vein; base of T2 with a few long setae laterally; S2 without protuberance anteriorly. 
DISTRIBUTION. Russia (Far East).

ETYMOLOGY. The name refers to the relatively small size of this new species.

\section{Genus Acanosema Kieffer, 1908}

Acanosema Kieffer, 1908: 360, 367, 407.

Type species: Acanosema rufum Kieffer, 1908, by original designation.

REMARKS. Kieffer (1908) differs Cardiopsilus from the Acanosema by long scapus which simple at the top (scapus shorter, with two lamellae on the top in Acanosema) and setose eye (bare in Acanosema). The new species described below demonstrate that the scapus has in reality restricted taxonomic value since the other two features are still could be used as diagnostic. However, these two features (pubescence of eye and shape of scapus top) are variable in the closest genera Acanopsilus (considering the two new species described below), Sinacra and Psilomma (Chemyreva \& Kolyada, 2020). On the base of these evidences we suggest that two genera Acanosema and Cardiopsilus can be classified in a single genus Acanosema with two subgenere: Acanosema s. str. and Cardiopsilus Kieffer.

\section{Key to species and subgenera of the genus Acanosema}

1. Eye bare. (Subgenus Acanosema Kieffer, 1908) ............................................................... 2

- Eye setose. (Subgenus Cardiopsilus Kieffer, 1908) ..................................................... 4

2. Occipital flange completely with thick collar of pubescence (Fig. 53); notauli tending to be obliterated in middle, not deep (Fig. 56); anterior scutellar pit strongly transverse (Fig. 56) …............................................................................. (A.) rufum Kieffer

- Occipital flange with less developed collar of pubescence, bare dorsally (Fig. 44); notauli distinct throughout, deep (Fig. 40); anterior scutellar pit weakly transverse to subcircular (Fig. 40)

3. Marginal vein strongly shorter than distance from it to basal vein; mesopleuron with subalar brige postero-dorsaly (Fig. 2); mandibles widely crossing at apex (Fig. 41); female S2 with more or less expressed protuberance at base (Fig. 42)

A. (A.) nervosum (Thomson)

- Marginal vein as long as distance from it to basal vein or slightly longer than it; mesopleuron without subalar brige structure postero-dorsaly (Fig. 60); mandibles weakly crossing at their tips (Fig. 61); female S2 without protuberance at base (Fig. 58)

A. (A.) tenuicorne (Kieffer)

4. Epicnemial brige present (Fig. 39); neck and pronotal collar situated almost in same plane (Fig. 39) A. (C.) epicnemium sp. $\mathrm{n}$.

- Epicnemial brige absent (Figs 30,67); neck and pronotal collar almost perpendicular to each other (Figs 30, 67) ..... 5

5. Side of pronotum antero-ventrally from pronotal spiracle bare (Fig. 30); female A15 slightly wider than A14 (Fig. 27) ..... A. (C.) dentigastrum sp. n.

- Side of pronotum antero-ventrally from pronotal spiracle setose (Fig. 67); female A15 as wide as A14 (Fig. 69) A. (C.) setigerum sp. $\mathrm{n}$. 
Acanosema (Cardiopsilus) dentigastrum Chemyreva et Kolyada, sp. n.

http://zoobank.org/NomenclaturalActs/92E9DEB8-24F1-4AD0-8ECD-366CCCFAC45D

Figs 25-32

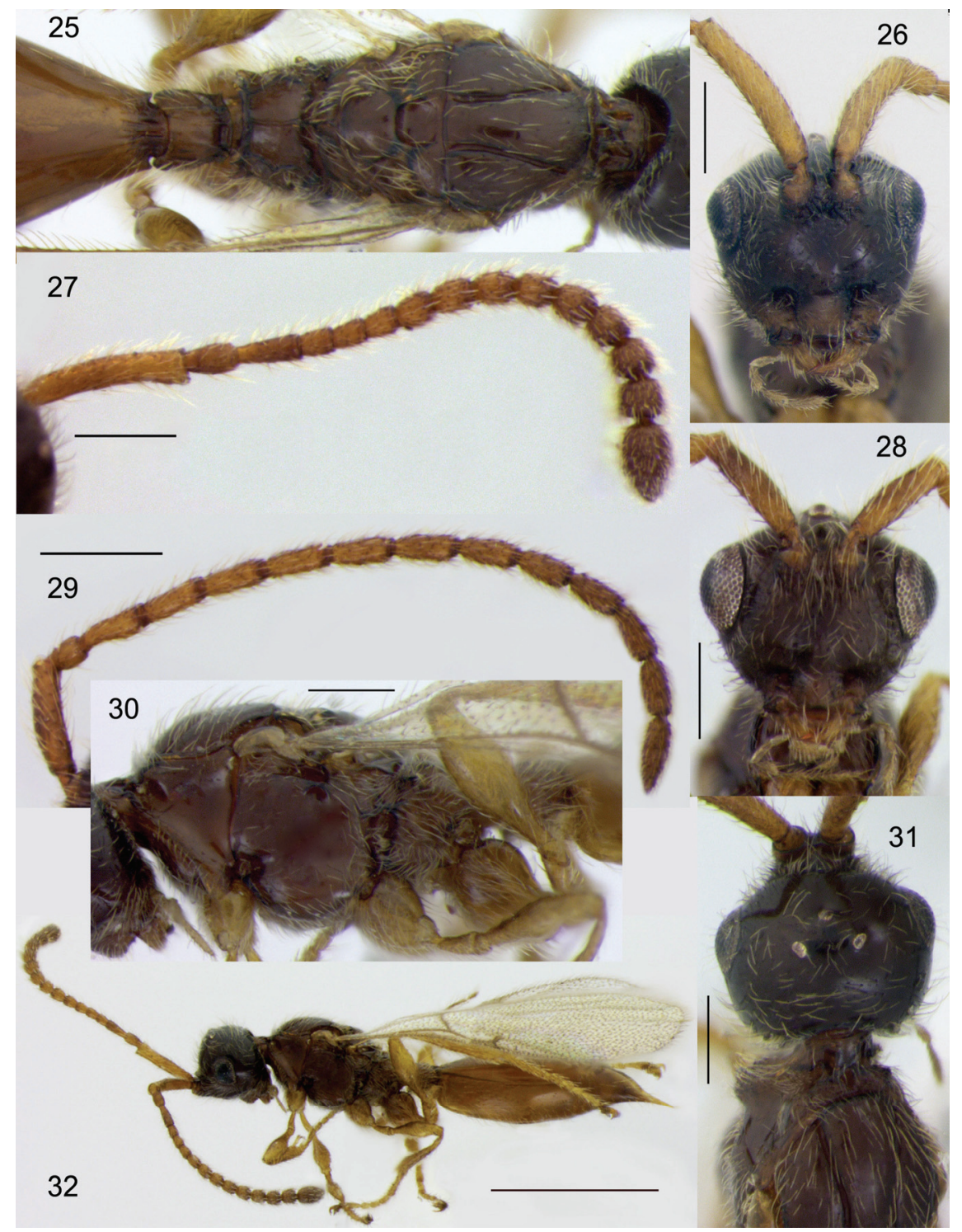

Figs 25-32. Acanosema dentigastrum sp. n., $+(25-27,30-32)$ and $\widehat{\partial}(28,29): 25-$ mesosoma and base of metasoma, dorsal view; 26, 28 - face; 27, 29 - antenna; 30 - mesosoma, lateral view; 31 - head, dorsal view; 32 - habitus, lateral view. Scale bar: $32-1 \mathrm{~mm}$; $26-31-0.2 \mathrm{~mm}$. 
TYPE MATERIAL. Holotype - $q$, Russia: Primorsky krai, vicinity of Anisimovka, Krinichnaya Mt., 14-15.VIII 2006, S. Belokobylskij (ZISP). Paratypes Russia: Primorsky krai: Lazo Nature Reserve, 9-17.VII 2008, 1 ô, A. Khalaim; Lazo Nature Reserve, 18 km SE of Lazo, 26.VIII 2006, 1 \%, S. Belokobylskij (all in ZISP).

DESCRIPTION. Female. Body length $2.8 \mathrm{~mm}$; fore wing length $2.1 \mathrm{~mm}$; antennae length $1.8 \mathrm{~mm}$.

Color. Head dark brown, mesosoma weakly pale than head; metasoma reddish brown; venation, tegulae, palpi, proximal part of antennae and legs pale brown; mandibles and distal part of antennae brown.

Head in dorsal view slightly nasiform, 0.92 times as long as wide, wider than mesosoma (38:32), smooth and covered by long semi-erect setae (Fig. 31). Temples gradually receding behind eye. Occipital flange very narrow, smooth. Head in lateral view slightly higher than length (20:19). Eyes setose, its largest diameter as long as malar space. Antennal shelf in front view with coriaceous sculpture below toruli. Face smooth. Head in front view with mouth conus (Fig. 26). Clypeus 0.8 times as high as wide. Tentorial pits large. Labrum small, semicircular, hardly visible. Mandibles simple.

Antennae slender, broadened apically. A1 0.7 times as long as width of head. Ratios of length to width of A1-A15 shown on Fig. 27.

Mesosoma slightly compressed, slightly higher than wide (41:34). Neck and pronotal collar almost perpendicular to each other (Fig. 30). Pronotal anterior corners weakly prominent, sharped. Pronotal collar, corners and pronotal pits covered by scattered long setae; neck dorsally and sides of pronotum bare. Mesoscutum 0.93 times as long as wide, convex, covered by fine long pubescent. Notauli deep and complete throughout. Anterior scutellar pit deep, large, rounded and bare. Scutellum large, convex, widened posteriorly. Axillar depression with one verriculate tubercle anteriorly. Mesopleuron bare medially, and pubescent elsewhere, with subalar bridge postero-dorsally and without epicnemial bridge antero-ventrally; epicnemial pit deep and weakly pubescent; mesopleural pit totally absent (Fig. 30). Metanotum narrow, with smooth and bare lateral sides and setose metascutellum; metascutellum with three short longitudinal keels, median keel the highest. Propodeum 0.55 times as long as wide, bare; median propodeal keel simple, plicae process complete (Fig. 25). Side of propodeum entirely finely pubescent, with two longitudinal keels. Legs slender.

Wing venation. Fore wing with distinct costal, subcostal and basal veins; radial cell open; distance from marginal vein to basal vein longer than marginal vein length (15:13); marginal vein 6 times longer than its wide; stigmal vein twice as long as wide of marginal vein. Poststigmal vein absent. Postmarginal vein nebulous. Radial vein as long as stigma vein.

Metasoma. Petiole weakly transverse 0.85 times as long as wide, weakly broadened posteriorly, with few longitudinal keels, bare dorsally and densely pubescent laterally and ventrally; posterior margin of petiole weakly arcuate. T2 anteriorly with few setae short longitudinal striation medially and small pointed projection laterally (Fig. 25); T3-T6 narrow, with fine micropunctation medially and few setae 
laterally; T7 and T8 elongate, compressed laterally, with few setae. S2 with large protuberance and dense pubescent at base and entirely pubescent posteriorly (Fig. 32); S3-S5 narrow, smooth, with few scattered setae; S6 with few scattered setae, smooth, distinctly elongate and compressed.

Male. Body length $2.3 \mathrm{~mm}$. Similar to female except following characters: antenna filiform, distinctly shorter than body length; antennomeres cylindrical, covered by semi-erect setae; A1 stout, about 0.5 times as long as width of head; A3 with shallow emargination and keel extending to 0.6 of A3 length; ratios of length to width of A1-A14 shown on Fig. 29; temples sharply receding behind eyes; genae sharply receding to mouthparts above eyes (Fig. 28); petiole elongate 0.8 times as wide as long; metasoma not compressed at top; T7 transverse; T8 and S8 semicircular; S2-S7 with numerous semi-recumbent scattered setae; S8 finely pubescent.

VARIATION. Female. Body length 2.8-3.6. Distance from marginal vein to basal vein longer to equal to marginal vein length.

DIAGNOSIS. This species distinctly differs from all other Acanosema species by the combination of the following characters: eyes setose; A1 with simple apical rim; mesopleuron with subalar bridge and without epicnemial bridge; T2 anteriorly with small pointed projection laterally; S2 with large protuberance at base.

DISTRIBUTION. Russia (Far East).

ETYMOLOGY. The name is derived from the Latin nouns dente and gaster and refers to the pointed basolateral projection on $\mathrm{T} 2$.

Acanosema (Cardiopsilus) epicnemium Chemyreva et Kolyada, sp. n. http://zoobank.org/NomenclaturalActs/DAD77850-9C5B-47DD-B414-EC8A9A32C8C8 Figs 33-39

TYPE MATERIAL. Holotype - , Russia: Primorsky krai, Suputinskiy zapovednik [Ussuriysky Nature Reserve], 1.VIII 1961 O. Kovalev (ZISP). Paratypes Russia: Primorsky krai: Ussuriysky Nature Reaserve, 26-30.VII 1972, 1 đ, M. Kozlov; $10 \mathrm{~km}$ SE of Ussuriysk, 12-19.VII 2001, 2 ô, S. Belokobylskij (all in ZISP).

DESCRIPTION. Female. Body length $2.0 \mathrm{~mm}$; fore wing length $1.8 \mathrm{~mm}$; antennae length $1.5 \mathrm{~mm}$.

Color. Head and mesosoma dark brown; metasoma, venation, tegulae, palpi, antennae, mandibles and legs pale brown.

Head in dorsal view slightly nasiform, as wide as long, slightly wider than mesosoma (16:15), smooth and covered by scattered upstanding setae (Fig. 36). Temples gradually receding behind eye. Occipital flange very narrow, with trace of sculpture medially. Head in lateral view slightly higher than length (35:32). Eyes setose, its largest diameter as long as malar space. Antennal shelf in front view with coriaceous sculpture below toruli. Face smooth. Head in front view with mouth conus (Fig. 34). Clypeus 0.75 times as high as wide. Tentorial pits large. Labrum small, semicircular, distinctly visible. Mandibles simple. 
Antennae slender, broadened apically. A1 0.6 times as long as width of head. Ratios of length to width of A1-A15 shown on Fig. 37.

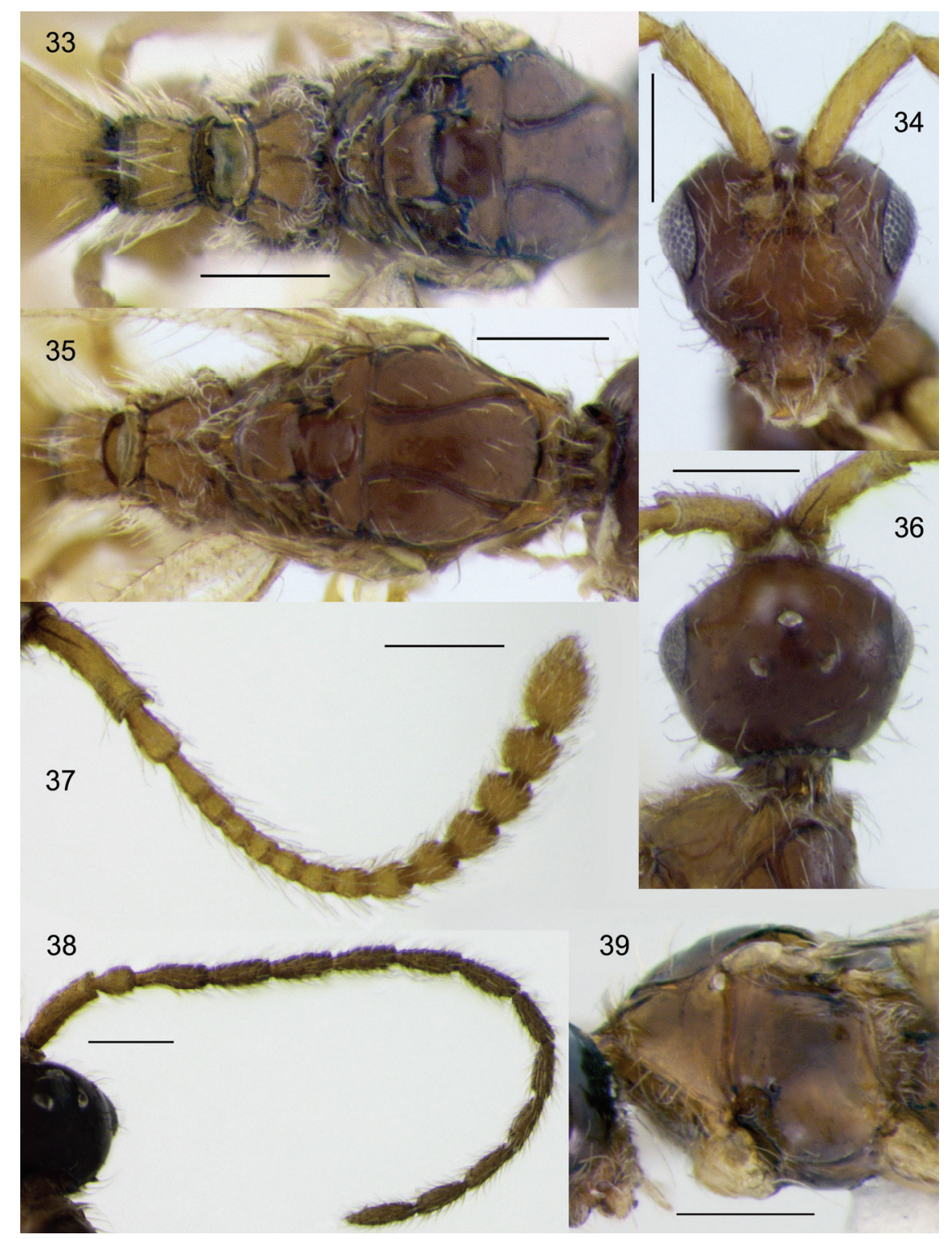

Figs 33-39. Acanosema epicnemium sp. n., 우 (33-37) and $\hat{\jmath}(38,39)$ : 33 - mesosoma and base of metasoma, dorsal view; 34 - face; 35 - mesosoma, dorsal view; 36 - head, dorsal view; 37, 38 - antenna; 39 - mesosoma, lateral view. Scale bar $0.2 \mathrm{~mm}$. 
Mesosoma weakly compressed, slightly higher than wide (32:29). Neck and pronotal collar situated almost in same plane (Fig. 39). Pronotal anterior corners weakly prominent, sharped. Pronotal collar, corners and pronotal pits covered by scattered long setae; neck dorsally and sides of pronotum bare. Mesoscutum 0.91 times as long as wide, almost flat, covered by few scattered long setae. Notauli deep and complete throughout. Anterior scutellar pit deep, large, rounded and bare. Scutellum large, convex, not widened posteriorly. Axillar depression with two small verriculate tubercle on inner side. Mesopleuron mainly bare medially, without subalar bridge postero-dorsally and with epicnemial bridge antero-ventrally; epicnemial pit deep and pubescent; mesopleural pit totally absent (Fig. 39). Metanotum narrow, with smooth and bare lateral sides and setose metascutellum; metascutellum with three short longitudinal keels, median keel the highest. Propodeum 0.58 times as long as wide, bare; median propodeal keel simple, plicae process complete (Fig. 35). Side of propodeum entirely pubescent, with two longitudinal keels. Legs slender.

Wing venation. Fore wing with distinct costal and subcostal veins; radial cell open; distance from marginal vein to basal vein slightly longer than marginal vein length (12:11); marginal vein 5.5 times longer than its wide; stigmal vein twice as long as wide of marginal vein. Poststigmal vein absent. Postmarginal and basal veins nebulous. Radial vein shorter than stigma vein.

Metasoma. Petiole as long as wide, weakly broadened posteriorly, with trace of longitudinal keels, sparsely pubescent dorsally and more densely laterally and ventrally; posterior margin of petiole not arcuate. T2 anteriorly with three grooves medially, median the longest (Fig. 33); T3-T6 narrow, bare and smooth medially and with few scattered setae laterally; T7 and T8 elongate, compressed laterally, with few setae. S2 with short longitudinal grooves and dense pubescent at base and weakly pubescent posteriorly; S3-S5 narrow, smooth, with few scattered setae; S6 with few scattered setae, smooth, distinctly elongate and compressed.

Male. Body length $1.8 \mathrm{~mm}$. Similar to female except following characters: antenna filiform, slightly shorter than body length; antennomeres cylindrical, covered by semi-recumbent setae; A1 stout, about 0.5 times as long as width of head; A3 with shallow emargination and keel extending to 0.7 of A3 length; ratios of length to width of A1-A14 shown on Fig. 38; largest diameter of eyes longer than malar space; petiole elongate $0.80-0.85$ times as wide as long; metasoma not compressed at top; T7 transverse; T8 and S8 semi-circular; S2-S8 with scattered setae.

VARIATION. Significant variation is not discovered because only one female is known.

DIAGNOSIS. This species distinctly differs from all other Acanosema species by the combination of the following characters: small (1.8-2.0) and sparsely setose species; eyes setose; A1 with simple apical rim; mesopleuron without subalar bridge and with epicnemial bridge; neck and pronotal collar situated almost in same plane (Fig. 39).

DISTRIBUTION. Russia (Far East).

ETYMOLOGY. The name refers to the presence of the epicnemial bridge in this species which usually absents in Cardiopsilus subgenus species. 
Acanosema (Acanosema) nervosum (Thomson, 1858)

Figs 2, 40-48

Cinetus nervosus Thomson, 1858: 165 .

MATERIAL. Moldova: Kotovskoe, 4.VI 1967, 3 đ̊, V. Tobias; Vilenevka, 6.VI 1967, 2 ภे, V. Tobias; Strasheni, 5.VI 1967, 3 ते, V. Tobias. Ukraine: Odessa Prov., Lisne Vill., Staromanzyrs'kyy Zakaznyk, 13.VI 1974, 1 ふै, D. Kasparyan; Kherson Prov., Askania-Nova National Reserve, 19.VI 1967, 1 $\sigma^{\lambda}$, V. Tobias. Russia: Republic of Crimea: Prokhladnoe Vill., Selbukhra Mt., 6.VI 1995, 1 \&, V. Kolyada (ZMUM); Karadag, 6-8.VI 1990, 1 \%, D. Kasparyan; same locality, 9.VI 1990, 1 ㅇ, A. Kotenko; Novgorodskaya oblast: Tychkino Vill., 4-17.VI 1998, 1 q, 2 J., V. Tobias; Leningradskaya oblast: 4 km W of Krasnitsy, MT, 5-30.VII 2007, 2 ㅇ, 1 J , D. Kasparyan; Moskovskaya oblast: vicinity of Stupino, 25.VII 1993 and 6.VIII 1995, 1 ㅇ, 1 ô, V. Kolyada (ZMUM); Stavropolsky krai: Shpakovsk [Mikhaylovsk], 7-18.VI 1988, 1 , 8 Ô, S. Belokobylskij; Kirovskaya oblast: Bolsheromanovo Vill., 4-10.VIII 1994, 1 ᄋ, 4 đ̃, V. Kolyada; Sverdlovskaya

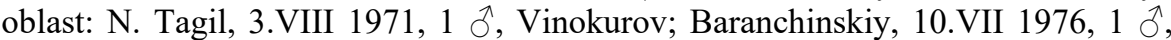
Potapova; Republic of Buryatia: Dungui Vill., 8-9.VIII 1970, 1 $\curvearrowright$, D. Kasparyan; Sakhalinskaya oblast: Sakhalin Island, Shmidta Peninsula, $30 \mathrm{~km} \mathrm{~N}$ of Okha Mt., 11.VIII 2003, 2 ठૈ, A. Lelej; Kuril Islands, Urup, Kama River, 7.VIII 2000, 1 ô, A. Lelej; Primorsky krai: Shkotovskiy Distr, Khualaza Mt [Krinichnaya Mt], 1200 m, 17.VIII 1972, 1 q, V. Kuslitzky. Abkhazia: Bzipi River, $43.363916^{\circ} \mathrm{N}$, $40.495772^{\circ} \mathrm{E}, 11-14$.VIII 2015, 2 9, V. Chemyreva; Lashipse River, 43.491564 ${ }^{\circ}$ N, 40.661648 E, 7-8.VIII 2015, 1 o, 1 ô, V. Chemyreva. Azerbaijan: Lenkoran, 3-7.V 1971, 2 q, V. Tobias; Hirkan National park, 16.VI 2009, 1 q, 1 ô, K. Tomkovich. All in ZISP if not stated otherwise.

VARIATION. Both sexes: head and mesosoma black to brown; marginal vein slightly shorter than distance from marginal vein to basal vein to 0.5 times as long as it; anterior scutellar pit transverse to subcircular. Female: body length 2.7-3.6; A12-A14 from elongate to transverse. Male: body length 2.2-3.8; petiole cylindrical to distinctly swollen medially, $0.6-0.8$ times as wide as long; A4 with keel extending to $0.4-0.5$ of this segment length.

DISTRIBUTION. United Kingdom, Norway, Sweden, Italy, Czech Republic, Poland, Slovakia, Hungary, Hercegovina, *Moldova, *Ukraine, *Russia (European part, Western and Eastern Siberia, Far East), *Abkhazia, *Azerbaijan.

Acanosema (Cardiopsilus) productum (Kieffer, 1908), comb. n.

Cardiopsilus productus Kieffer, 1908: 360, 407.

DISTRIBUTION. Austria, Czech Republic, Finland, Hungary, Switzerland.

REMARKS. This species is still not found in Russia. We have studied only several males and females from Czech Republic. Since the discovery of the species is still possible in Russia we include the species in the key above. 


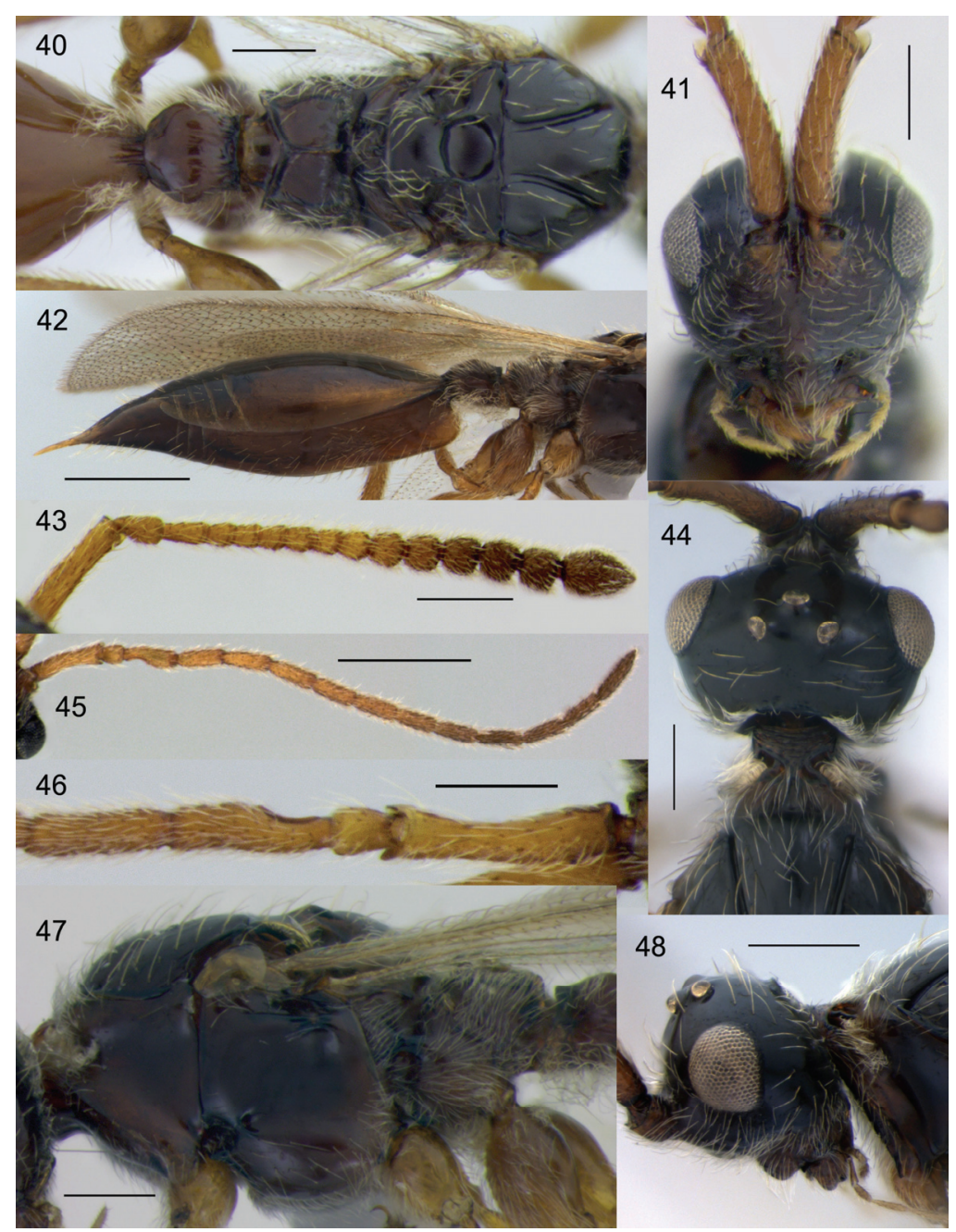

Figs 40-48. Acanosema nervosum, ㅇ $(40-44,47,48)$ and $\widehat{\jmath}(45,46): 40$ - mesosoma and base of metasoma, dorsal view; 41 - face; 42 - metasoma, lateral view; 43, 45 - antenna; 44,48 - head and propodeum, dorsal view (44) and lateral view (48); 46 - antenna, proximal part; 47 - mesosoma, lateral view. Scale bar: 42 , $45-0.5 \mathrm{~mm}$; 40, 41, 43, 44, 46-48 - $0.2 \mathrm{~mm}$.

\section{Acanosema (Acanosema) rufum Kieffer, 1908}

Figs 49-56

Acanosema rufum Kieffer, 1908: 411.

MATERIAL. Russia: Leningradskaya oblast: $55 \mathrm{~km} \mathrm{~S}$ of St. Petersburg, MT, 5-30.VII 2007, 1 $\hat{\jmath}$, D. Kasparyan; Petrodvorets, 5.VII 1970, 1 $\hat{\sigma}$, V. Trjapitzin; Krasnodarsky krai: 8 km SW of Temryuk, 17.IX 2007, 1 q, S. Belokobylskij; Sochi City, Lazorevskoe, 2-10.V 1973 and 8.V 1983, 2 §̂, V. Tobias. All in ZISP. 
VARIATION. Both sexes: median propodeal keel simple or bifurcate posteriorly; marginal vein $0.64-0.83$ times as long as distance from it to basal vein. Male: body length $2.7-3.2 \mathrm{~mm}$.

DISTRIBUTION. United Kingdom, Germany, Hungary, *Russia (European part).
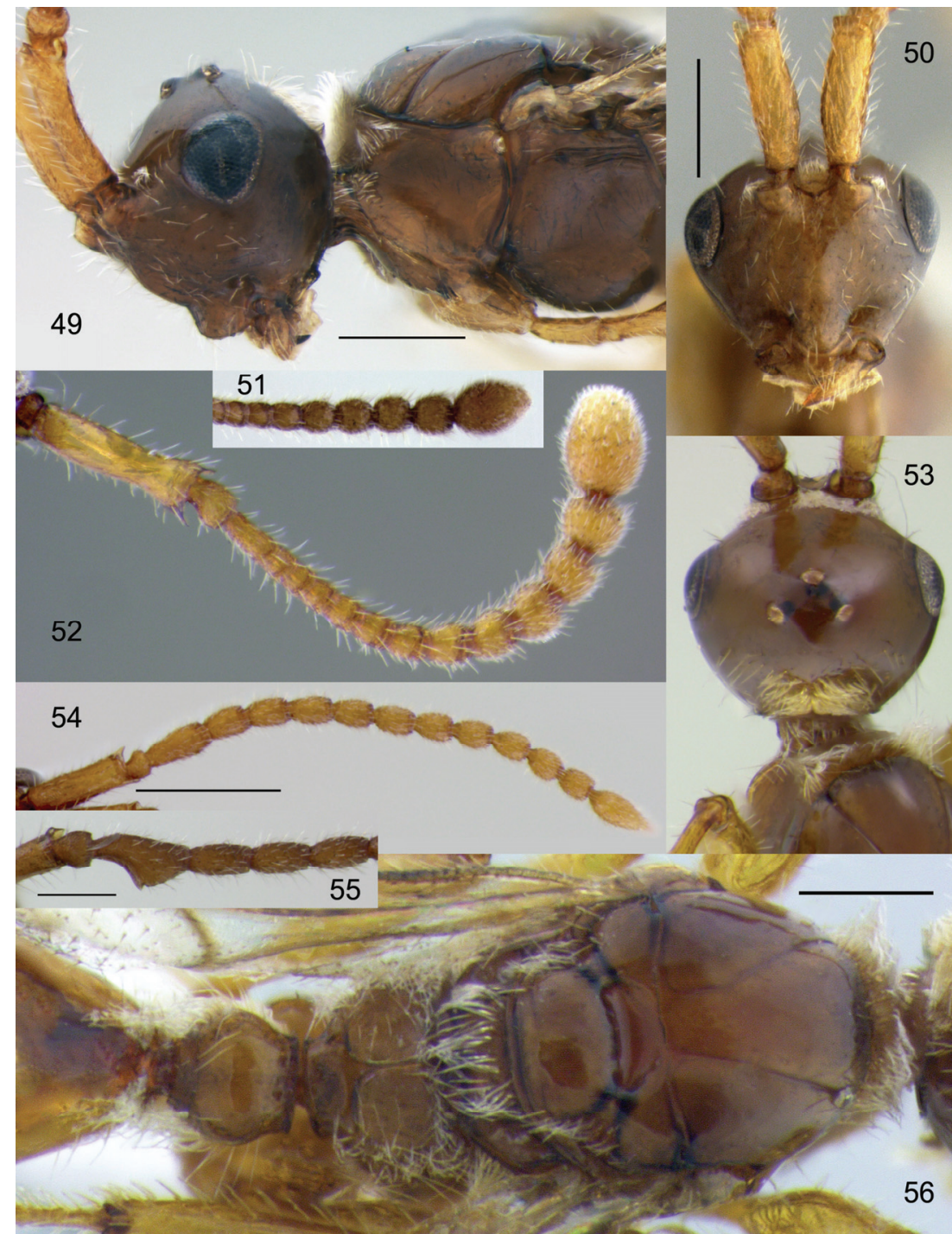

Figs 49-56. Acanosema rufum, $\varnothing(49-53,56)$ and $\partial(54,55)$ : 49 - head and mesosoma, lateral view; 50 - face; 51 - antenna, distal part, dorsal view; 52 - antenna, lateral view; 53 head, dorsal view; 54 - antenna, lateral view; 55 - antenna, proximal part; 56 - mesosoma and base of metasoma, dorsal view. Scale bar: $54-0.5 \mathrm{~mm}$; 49, 50, 55, $56-0.2 \mathrm{~mm}$. 


\section{Acanosema (Acanosema) tenuicorne (Kieffer, 1908)}

Figs 57-63

Psilomma tenuicornis Kieffer, 1908 : 421.

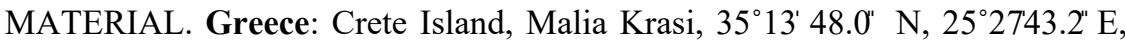
YPT, 13-20.V 2014, 1 , V. Kolyada (ZMUM). Russia: Yaroslavlskaya oblast: Berditsino, 9.VI, 1 +, A. Yakovlev; Evreyskaya Avtonomnaya oblast: Ridde Vill., Khingan, Amur River, 12-15.VIII 2003, 1 क, S. Belokobylskij; Primorsky krai: Partizansk Distr., Molchanovka, 18.VI-1.VII 1972, 1 ㅇ, 1 ふ̋, M. Kozlov; same locality, 29.VI 1972, 1 ㅇ, V. Kuslitzky. All in ZISP if not stated otherwise.

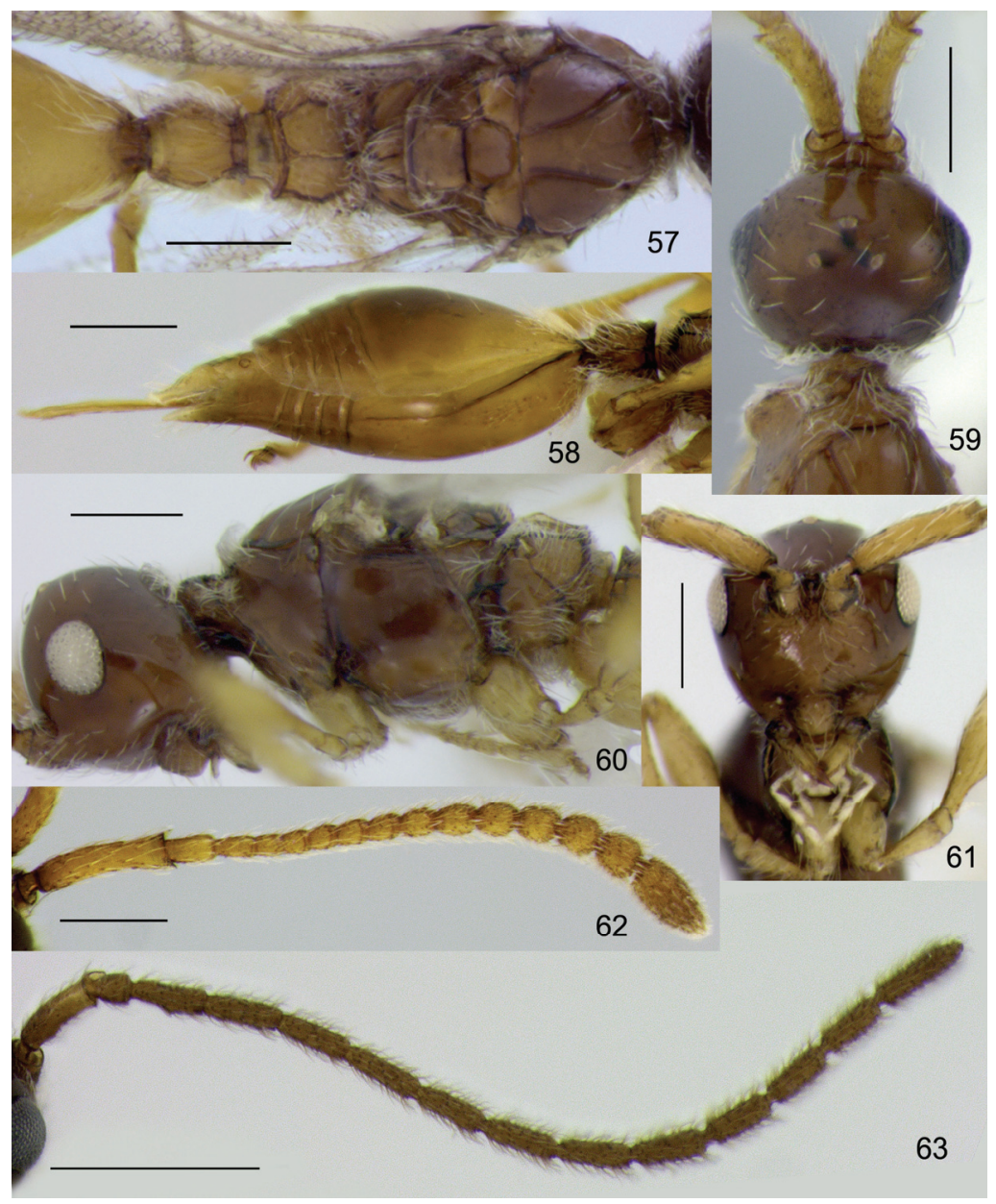

Figs 57-63. Acanosema tenuicorne, ㅇ (57-62) and $\widehat{\partial}(63): 57-$ mesosoma and base of metasoma, dorsal view; 58 - metasoma, lateral view; 59 - head, dorsal view; 60 - head and mesosoma, lateral view; 61 - face; 62,63 - antennae. Scale bar: $63-0.5 \mathrm{~mm} ; 57-62-0.2 \mathrm{~mm}$. 
VARIATION. Marginal vein as long as distance from it to basal vein or slightly longer than it. Female: body length $2.2-2.7 \mathrm{~mm}$; petiole weakly transverse to elongate.

DISTRIBUTION. United Kingdom, Germany, Denmark, Switzerland, *Greece, *Russia (European part, Far East).

Acanosema (Cardiopsilus) setigerum Chemyreva et Kolyada, sp. n.

http://zoobank.org/NomenclaturalActs/C0E34B04-E01C-4891-85FE-280F7A313A67

Figs 64-69

TYPE MATERIAL. Holotype - $q$, Russia: Sakha Republic (=Yakutia), Tomtor, soil traps, 8-27.VIII 1990, S. K. Alekseev leg. (ZISP). Paratypes - Russia: Sakha Republic, Nizhny Bestyakh, Disogudai Lake, soil traps, 9-15. VIII 1990, 1 , S. K. Alekseev (ZISP). Sweden: S:Sm.Torsås. Tjärekulla, 18.VI.1989, 1 q, R. Danielsson (NMPC).

DESCRIPTION. Female. Body length $3.3 \mathrm{~mm}$; fore wing length $1.1 \mathrm{~mm}$; antennae length $1.8 \mathrm{~mm}$.

Colour. Head, mesosoma and distal part of antenna dark brown; metasoma, venation, proximal half of antennae, mandibles and legs reddish brown; palpi pale brown.

Head in dorsal view weakly nasiform, 1.1 times as long as wide, as wide as mesosoma, smooth and covered by numerous scattered semi-recumbent setae (Fig. 65). Temples gradually receding behind eye. Occipital flange very narrow, bare. Head in lateral view slightly higher than length (38:35). Eyes setose, its largest diameter shorter than malar space (13:16). Face mainly smooth, only with coriaceous sculpture below toruli. Head in front view with mouth conus (Fig. 68). Clypeus 0.67 times as high as wide. Tentorial pits small. Labrum small, semicircular, distinctly visible. Mandibles simple.

Antennae slender, weakly broadened apically. A1 0.7 times as long as width of head. Ratios of length to width of A1-A15 shown on Fig. 69.

Mesosoma slightly compressed, slightly higher than wide (19:17). Neck and pronotal collar almost perpendicular to each other (Fig. 67). Pronotal anterior corners weakly prominent, rounded. Pronotal collar, corners, pronotal pits and areas in front of pronotal spiracle covered by scattered long setae; neck dorsally and sides of pronotum bare. Mesoscutum 0.82 times as long as wide, convex, covered by scattered long setae. Notauli deep and complete throughout. Anterior scutellar pit deep, large, rounded and bare. Scutellum large, convex, weakly widened posteriorly. Axillar depression with one verriculate tubercle anteriorly. Mesopleuron bare medially and pubescent dorsally and ventrally, without subalar bridge postero-dorsally and epicnemial bridge antero-ventrally; epicnemial pit deep and densely pubescent; mesopleural pit totally absent (Fig. 67). Metanotum narrow, with almost smooth and bare lateral sides and setose metascutellum; metascutellum with three short longitudinal keels, median keel the highest. Propodeum 0.4 times as long as wide, bare; median propodeal keel bifurcate from base, plicae process complete (Fig. 66). Side of propodeum entirely pubescent, with two longitudinal keels (Fig. 67). Legs slender. 


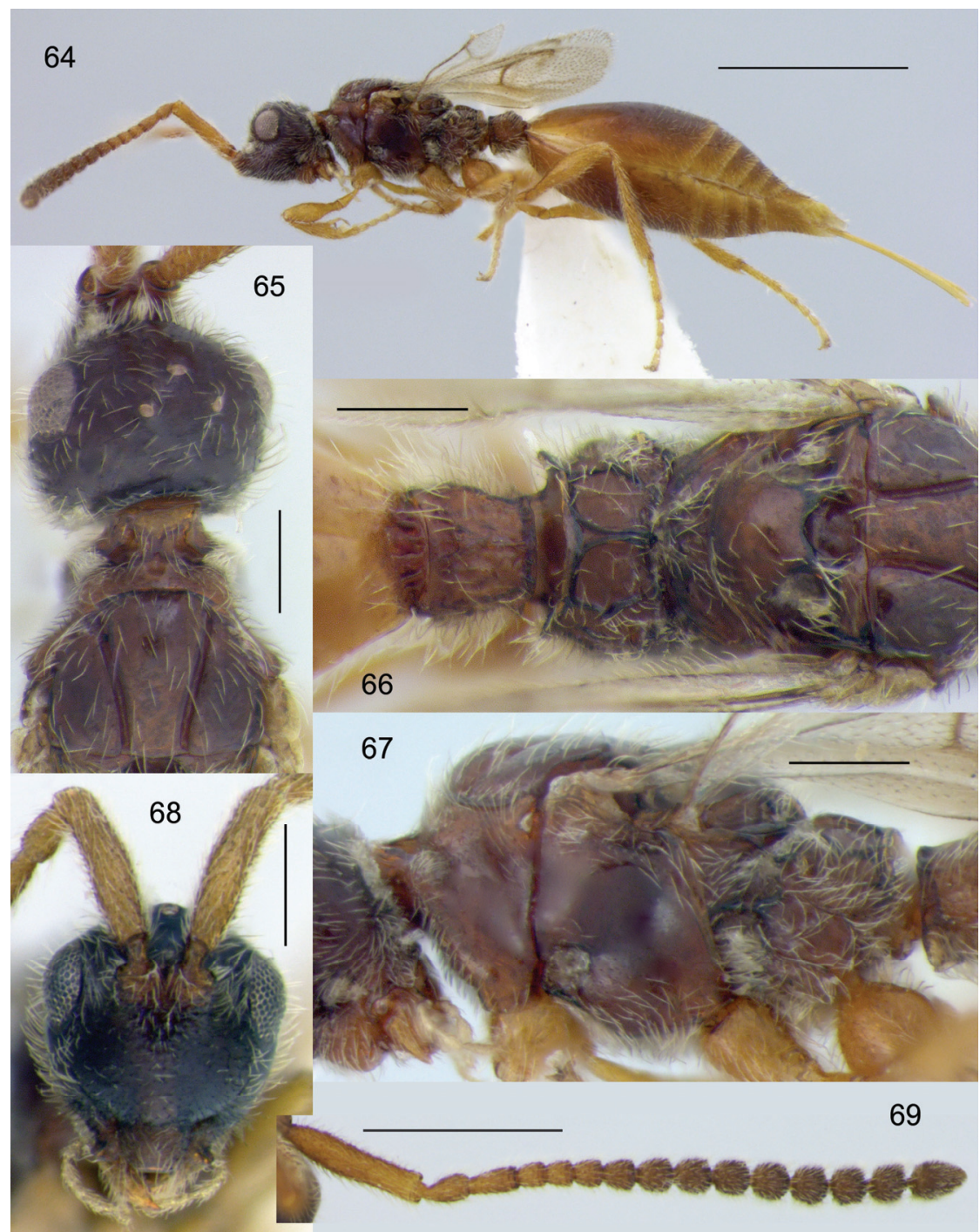

Figs 64-69. Acanosema setigerum sp. n., 9 (holotype): 64 - habitus, lateral view; $65-$ head and propodeum, dorsal view; 66 - mesosoma and base of metasoma, dorsal view; 67 mesosoma, lateral view; 68 - face; 69 - antenna. Scale bar: $64-1 \mathrm{~mm}$; $69-0.5 \mathrm{~mm}$; $65-68-$ $0.2 \mathrm{~mm}$.

Wing venation. Fore wing short, reaching to middle of T2, with distinct costal, subcostal, basal and marginal veins; radial cell open; distance from marginal vein to basal vein as long as marginal vein; marginal vein 4.4 times longer than its width; stigmal vein indistinct, nebulous. Poststigmal and postmarginal veins absent. Radial vein absent. 
Metasoma. Petiole 0.8 times as long as wide, weakly broadened posteriorly, with inrregular sculpture and median longitudinal keel which higher projecting posteriorly, bare dorsally and pubescent laterally and ventrally; posterior margin of petiole weakly arcuate. T2 with few setae, short longitudinal grooves at base (Fig. 66), and covered by numerous homogeneous upstanding short setae in posterior half; T3-T6 and S3-S5 narrow, entirely with upstending short setae and with micropunctuation medially; T7 and T8 elongate, compressed laterally, pubescent. S2 with very small protuberance and dense pubescent at base and entirely pubescent posteriorly (Fig. 64); S6 with numerous setae, smooth, distinctly elongate and compressed.

Male. unknown

VARIATION. Body length $3.0-3.3 \mathrm{~mm}$. Genae in front view more or less convex. Holotype with short wings, paratypes with wings broken at base and with long wings almost reaching to the top of metasoma. Distance from marginal vein to basal vein as long as marginal vein to slightly longer; marginal vein $4.4-5.2$ times longer than its width; stigmal vein nebulous to distinct, twice as long as width of marginal vein. Radial vein absent in brachypterous specimen or as long as stigma vein in macropterous specimen. Median keel on petiole distinct and quite high posteriorly to absent.

DIAGNOSIS. This species distinctly differs from all other Acanosema species by the combination of the following characters: eyes setose; A1 with simple apical rim; A15 as wide as A14; side of pronotum antero-ventrally from pronotal spiracle setose; mesopleuron without subalar bridge and epicnemial bridge; S2 with very small protuberance at base; posterior part of $\mathrm{T} 2$ and $\mathrm{S} 2, \mathrm{~T} 3-\mathrm{T} 7$ and $\mathrm{S} 2-\mathrm{S} 6$ covered by homogenous semi-erect pubescence.

DISTRIBUTION. Russia (Sakha Republic), Sweden.

ETYMOLOGY. The name is derived from the Latin adjective setigeris (bristly) and refers to homogenous short pubescence of metasomal terga and sterna.

\section{Genus Polypeza Förster, 1856}

Polypeza Förster, 1856: 123, 127.

Type species: Polypeza pergandei Ashmead, 1893, by subsequent monotypy of Ashmead, 1893: 385, 387.

\section{Key to species of the genus Polypeza}

(male of $P$. dalgaardi unknown)

1. Female antennae with $\mathrm{A} 1$ as long as $\mathrm{A} 2$ and $\mathrm{A} 3$ measured together (Figs 72, 73); S2 without protuberance anteriorly in lateral view (Fig. 70); grooves at base of T2 moderately long, different in length (Fig. 71) P. dalgaardi Buhl

- Female antennae with A1 distinctly longer than A2 and A3 measured together (Fig. 74); S2 with weak or distinct protuberance anteriorly in lateral view (Fig. 74); grooves at base of T2 short, similar in length (Fig. 77) . P. ciliata (Thomson) 


\section{Polypeza dalgaardi Buhl, 1992}

Figs 70-73

Polypeza dalgaardi Buhl, 1992: 79.

TYPE MATERIAL EXAMINED. Holotype - + , Denmark: "DK, NE-Zealand/ FAERGELUNDEN/ 55 51' N, 12 02' E/ Peter N. Buhl leg./ 31.VIII 1986", “ZMUC/ 00021254". Paratypes - Denmark: "DK, NE-Zealand/ FAERGELUNDEN/ 55 51' N 12 02' E/ Peter N. Buhl leg./ 4.IX 1987”, 1 q; "DK, NE-Zealand/ Sømmer Skov/ 55 48' N 11 52' E/ Peter N. Buhl leg./ 6.IX 1987”, 1 ㅇ.

OTHER MATERIAL EXAMINED. Russia. Moskovskaya oblast: Domodedovo, 26.V 1988, 2 ㅇ, V. Kolyada; Altaisky krai: 8 km of Biysk, Ust'-Katun', 7.VII 2007, 1 9, A. Khalaim; Krasnoyarsky krai: Stolby National Park, 14.VIII 2003, 1 , A. Kuvaev; Irkutskaya oblast: near Irkutsk City, 21.VI 1971, 1 \&, D. Kasparyan (all in ZISP).

VARIATION. Body length 2.4-2.6. No distinct variation of the morphological characters was found in the studied specimens.

DISTRIBUTION. Denmark, Russia (European part, Western and Eastern Siberia).

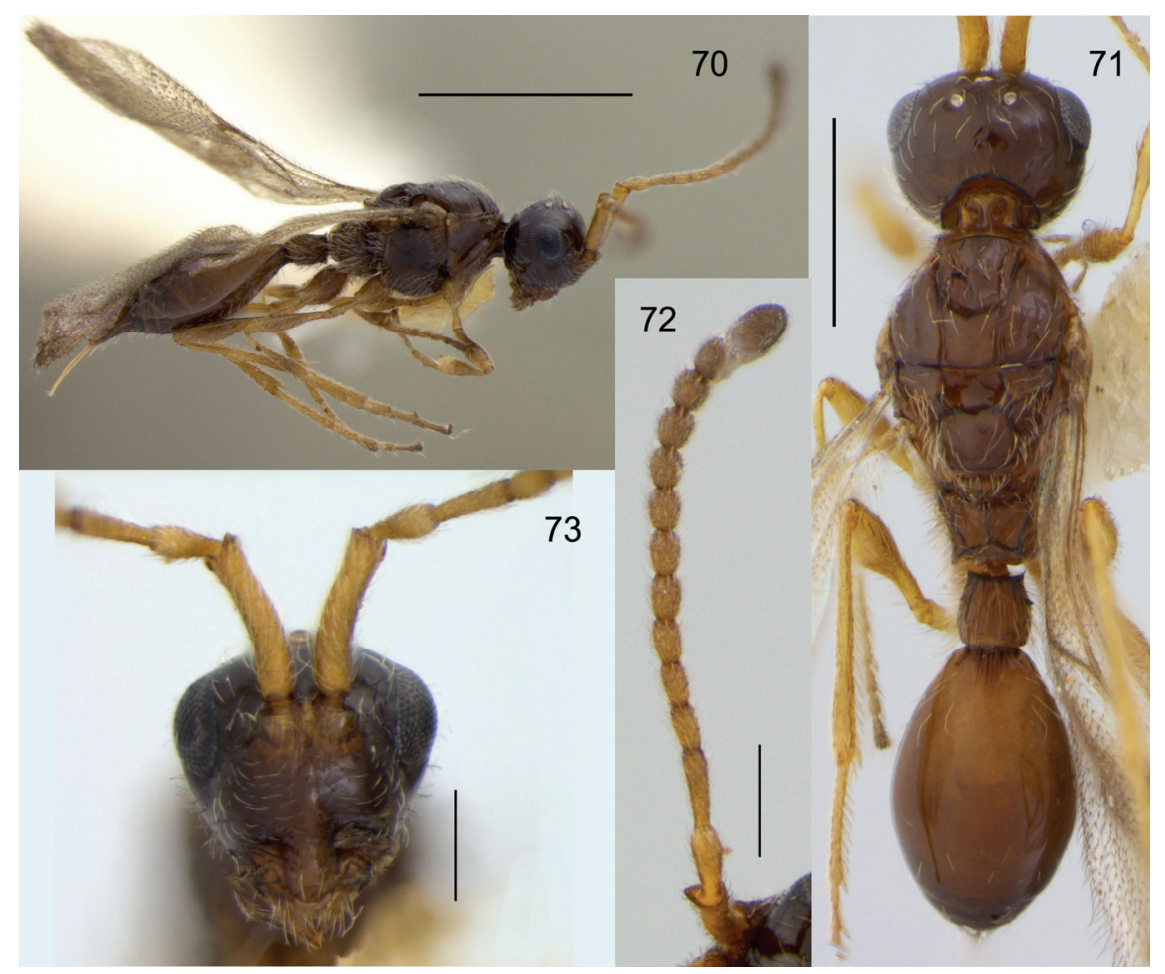

Figs 70-73. Polypeza dalgaardi, ㅇ (holotype): 70 - habitus, lateral view; 71 - whole body, dorsal view; 72 - antennae; 73 - face. Scale bar: $70-1 \mathrm{~mm} ; 71-0.5 \mathrm{~mm} ; 72,73-0.2$ $\mathrm{mm}$. 


\section{Polypeza ciliata (Thomson, 1858)}

Figs 74-78

Belyta (Opazon) ciliata Thomson, 1858: 179.

MATERIAL. Ukraine: Kharkiv Prov., Krasnokuts, 17.VII 1992, 1 ๙ , N. Storozheva. Russia: Novgorodskaya oblast: Pestovo Distr., Tychkino Vill., 4-15.VIII 1992, 13-14.VII 1992, 13-18.VIII 1990, 7 q, V. Tobias; Leningradskaya oblast:

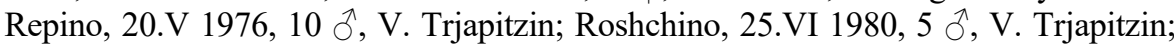
Sosonovo, 2.VI 1973, 1 +, D. Kasparyan; Moskovskaya oblast: Moscow City, Krylatskoe, Rublevskiy forest, VII 2002, 1 ㅇ, 1 $\hat{\text {, }, ~ V . ~ K o l y a d a ~(Z M U M) ; ~ M o s c o w ~}$

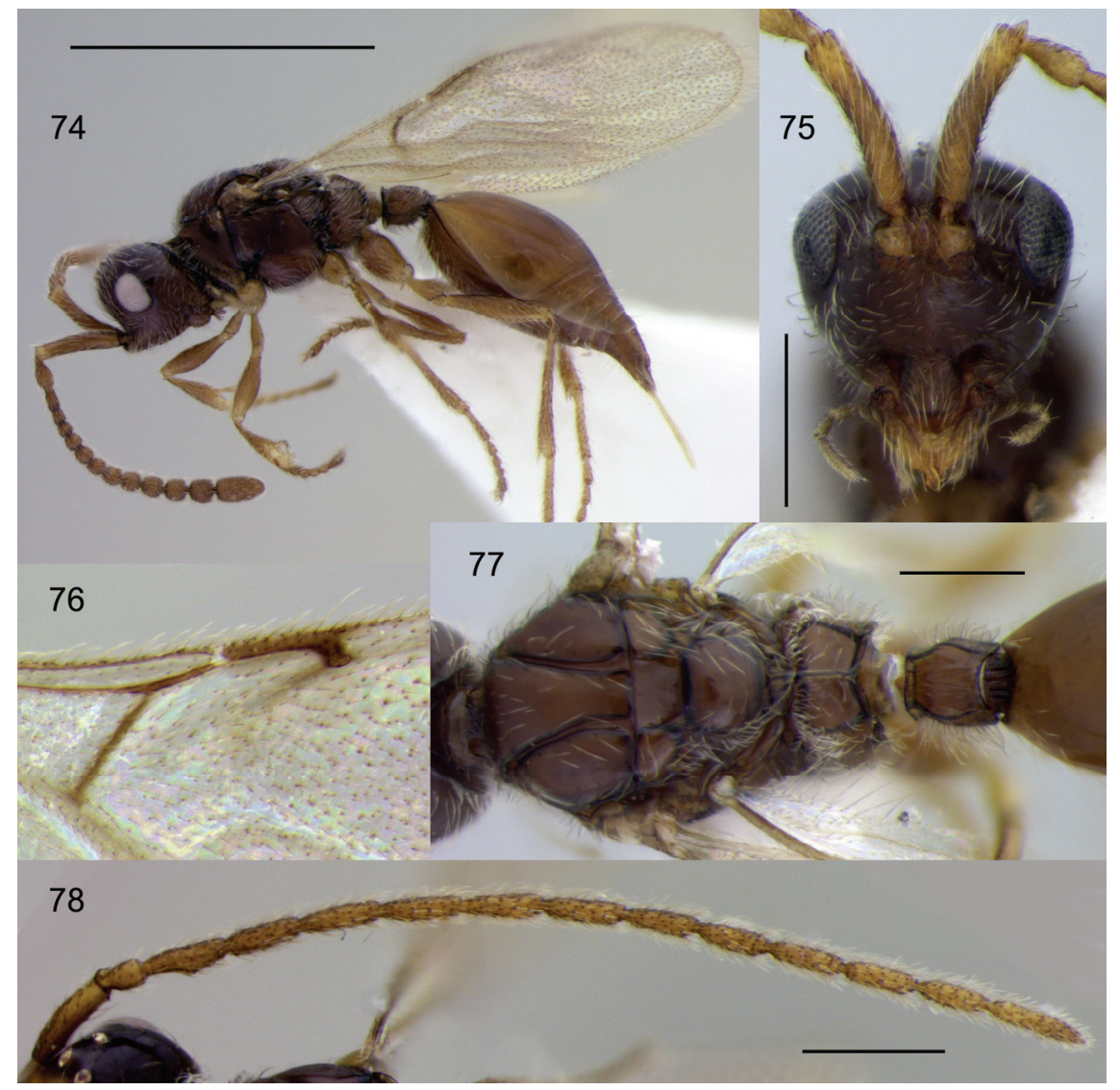

Figs 74-78. Polypeza ciliata, + (74-77) and $ð$ (78): 74 - habitus, lateral view; 75 - face; 76 - forewing venation; 77 - mesosoma and base of metasoma, dorsal view; 78 - antennae. Scale bar: $74-1 \mathrm{~mm} ; 75-78-0.2 \mathrm{~mm}$. 
City, Bitsa Park, 21.IX 1993, 28.VII 1994, 27.IX 1995 and VII 2004, 6 ㅇ, 2 ふึ, V. Kolyada (ZMUM); Malakhovka, 26.VII-1.VIII 1994, 9 q, 10 ๙, M. Mostovski (ZMUM); Komi Republic, 70 km S of Vorkuta, 11.VIII 1972, 1 , , D. Kasparyan; vicinity of Salekhard, 20.VIII 1972, 3 ㅇ, D. Kasparyan; Seyda, Ysa River, 13.VIII 1972, 3 क, Kasparyan; Sverdlovskaya oblast: Nizhny Tagil, VI 1971, 1 , 1 , Lebedkina; same locality, 3.VIII 1971, 1 \%, Vinokurov; Krasnoyarsky krai: Taymyr Peninsula, Kresty Vill., 24.VII 1971, 1 , I. Sykacheva \& V. Zherikhin; vicinity Taymyr Lake, 25.VII-18.VIII 1994, 2 ㅇ, 5 ô, K. Makarov; Tyva Republic: 45 km E of Chadan, vicinity of Ak-Durug, 7.VIII 2009, 2 , , S. Belokobylskij; Sakhalinskaya oblast: Sakhalin Island, vicinity of Nevelsk, 9.VI 1972, 2 ㅇ, 2 §̊, M. Kozlov; Kholmsk Distr., 10.VI 1972, 2 , 1 ô, M. Kozlov; Primorsky krai: Shkotovsky Distr, Khalaza Mt [Krinichnaya Mt], 6-7.VII 1972, 1 +, M. Kozlov; Shkotovsky Distr., Suvorovka River, 29.VII 1972, 1 क, V. Kuslitzky; Ussuriysk Distr., Gornotaezhnoe, 22-23.VII 1972, 1 + , V. Kuslitzky. Kazakhstan: East Kazakhstan Prov., Staropyatigorskoe, VIII 1962, 12 q, 22 đ̃, V. Tobias. Mongolia: $10 \mathrm{~km} \mathrm{~N}$ of Erdene, 7.X 1975, 5 q, 4 $\widehat{\jmath}, \mathrm{V}$. Sugonyaev. All in ZISP if not stated otherwise.

VARIATION. Both sexes: propodeal median keel simple to bifurcate; distance from marginal to basal vein $0.5-0.8$ times as long as marginal vein. Female: body length 1.8-2.4; antennae is very variable with A4-A14 all elongate to all subquadrate (or circular) and transverse; base of S2 with weak to large protuberance; petiole cylindrical to widened posteriorly, $0.75-1.0$ times as wide as long. Male: body length 1.7-2.5; A4 with shallow to deep excavation and keel with projection at base or without it (Fig. 78).

DISTRIBUTION. Palaearctic: Iceland, Norway, Germany, Italy, Sweden, Czech Republic, Austria, Poland, Hungary, Finland, Estonia, *Ukraine, Russia (*European part, Western and Eastern Siberia, *Far East), *Kazakhstan, *Mongolia, Japan. Nearctic: Canada, USA.

\section{Genus Psilomma Förster, 1856}

Psilomma Förster, 1856: 128, 130, 132.

Type species: Psilomma fusciscapis Förster, 1861, by subsequent monotypy of Förster, 1861: 43.

\section{Key to species of the genus Psilomma}

1. Anterior scutellar pit bare inside (Figs 81,88 ); head with sparsely pubescence above: pubescence of gena distinctly denser than pubescence of vertex and occiput (Figs 82, 86); male A3 without projection at base of emargination (Figs 84, 92)

- Anterior scutellar pit pubescent inside, covered by upstanding setae (Figs 94, 97, 101, $105)$; head with dense pubescence above: pubescence of gena, vertex and occiput similar (Figs 97, 101); male A3 with small projection at base of emargination (Figs 99, 106) ....... 
2. Pronotal anterior corners weakly projecting, rounded (Fig. 82); medial furrow at the base of T2 deeper, wider and always longer than lateral furrows (Fig. 81); S2 of female without round projecting at base in lateral view (Fig. 79) P. calaris sp. $\mathbf{n}$.

- Pronotal anterior corners strongly projecting, sharped (Fig. 86); medial furrow at the base of T2 no deeper, no longer (rare slightly longer) and no wider than lateral furrows (Fig. 88); S2 of female with round projecting at the base in lateral view .... P. dubia Kieffer

3. Face slightly wider than high (Fig. 95); female A9-A14 about as wide as long (Fig. 96); male antenna yellow or pale brown, A3-A14 with short recumbent pubescence (Figs 98, 99) P. fuscicornis Kieffer

- Face slightly higher than wide (Fig. 102); female A9-A14 distinctly longer than wide (Fig. 103); male antenna brown, A3-A14 with long semi-erect pubescence (Figs 104, 106) P. fusciscapis Förster

\section{Psilomma calaris Chemyreva et Kolyada, sp. n.}

http://zoobank.org/NomenclaturalActs/C2829679-37E0-4D63-B5AD-7F59B6B823A1

Figs 79-85

TYPE MATERIAL. Holotype - + , Russia: Primorsky krai: 20 km SW of Krounovka, 2-5.VIII 1993, S. Belokobylskij (ZISP). Paratypes (all in ZISP if not stated otherwise) - Russia: Primorsky krai: Ussuriysk Nature Reserve, 26-30 VII.1972, 1 ๙ै, M. Kozlov; Lazovskiy Nature Reserve, Tachingouza Bay, 7-8.VIII 1972, 1 त, M. Kozlov; Lazovskiy Nature Reserve, 9-17.VII 2008, 1 ते, A. Khalaim; vicinity of Anisimovka, Krinichnaya Mt., 14-15.VIII 2006, 2 ō, S. Belokobylskij; Sakhalinskaya oblast: Kuril Islands, Urup, Kama River, 7.VIII 2000, 1 $\widehat{\jmath}$, A. Lelej; Japan: Honshu, Yamanashi Pref., Koshushi, Hikawa Valley, Flight intercept trap, 20-27.V 2017, 1 , 3 §, J. Imura (KPMNH).

DESCRIPTION. Female. Body length $2.5 \mathrm{~mm}$; fore wing length $2.6 \mathrm{~mm}$; antennae length $2.1 \mathrm{~mm}$.

Colour. Head, mesosoma black; metasoma and distal part of antennae dark brown; mandibles, venation, tegulae, palpi and legs yellowish brown.

Head in dorsal view weakly nasiform (Fig. 82), wider than long (11:10), wider than mesosoma (11:10), smooth, covered with recumbent pubescence, more short and dense on face and genae. Temples sharply receding behind eye. Occipital flange very narrow, smooth. Head in lateral view higher than length (23:20). Malar space shorter than largest diameter of eye $(15: 17)$. Eyes coved with short pubescence. Antennal shelf in front view with fine coriaceous sculpture below toruli. Head in front view with weak mouth conus (Fig. 80). Clypeus 0.82 times as high as wide. Tentorial pits small. Labrum semicircular, weakly visible. Mandibles simple.

Antennae slender, weakly broadened apically. Ratios of length to width of A1-A12 in dorsal view shown on Fig. 83.

Mesosoma weakly compressed, slightly higher than wide (24:21), in dorsal view longer than wide (24:33). Neck bare, with median carina and lateral deep depression (Fig. 82). Sides of pronotum bare; pronotal collar pubescent. Epomia sharp, strongly prominent, interrupted by pronotal pit; pronotal pit finely pubescent. Mesoscutum 0.75 times as long as wide, convex, pubescent with semi-erect setae. Notauli deep 
and complete throughout. Anterior scutellar pit deep, large, bare and rounded. Scutellum large, convex, widened posteriorly. Axillar depression without verriculate tubercles. Mesopleuron mainly pubescent but bare medially and postero-medially,

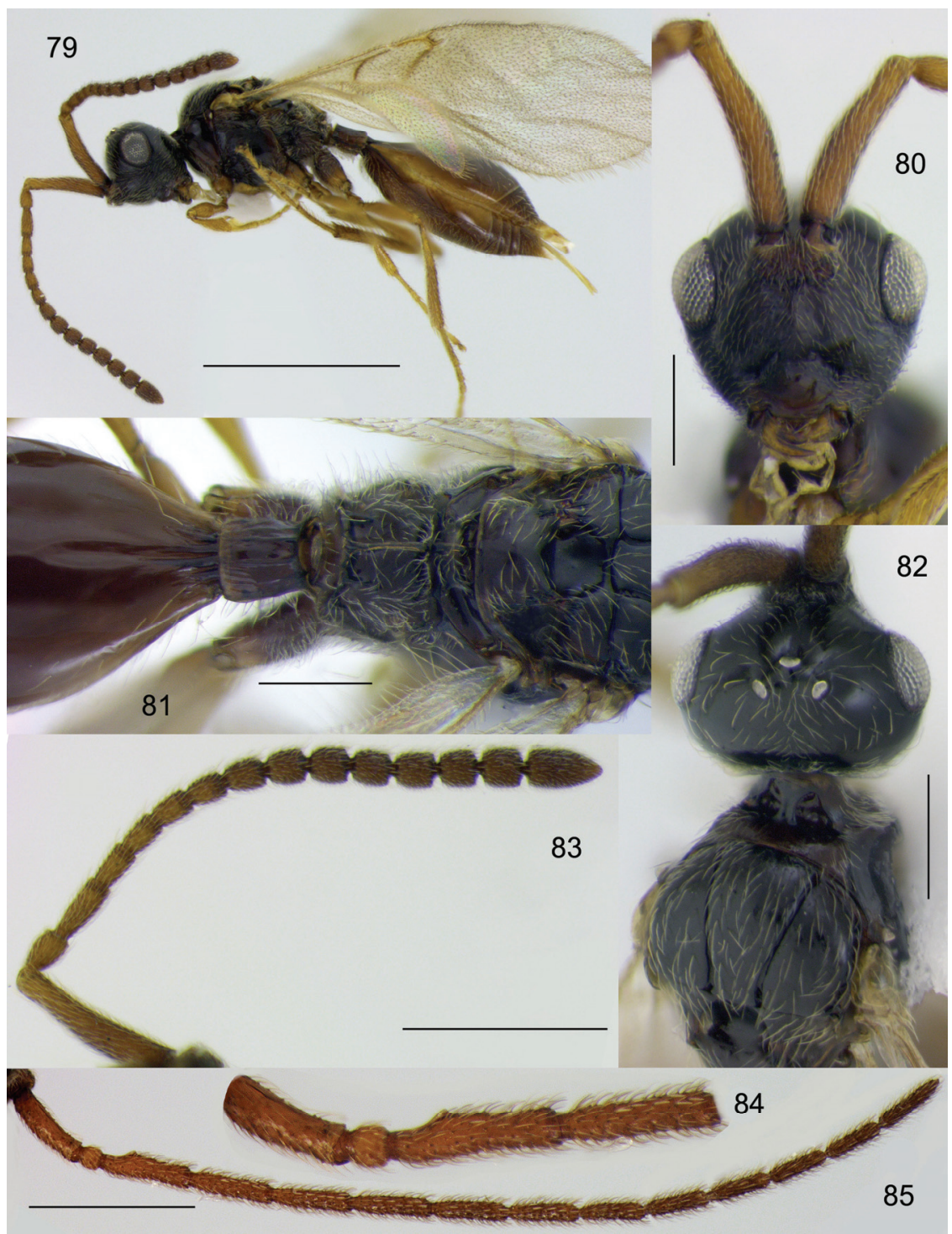

Figs 79-85. Psilomma calaris sp. n., + (79-83) and $\delta(84,85): 79$ - habitus, lateral view; 80 - face; 81 - mesosoma and base of metasoma, dorsal view; 82 - head and mesosoma, dorsal view; 83,85 - antennae; 84 - antenna, proximal part. Scale bar: $79-1 \mathrm{~mm}$; 83, $85-$ $0.5 \mathrm{~mm} ; 80-82-0.2 \mathrm{~mm}$. 
with subalar bridge postero-dorsally and epicnemial bridge antero-ventrally; epicnemial pit not deep, pubescent; mesopleural pit totally absent. Metanotum narrow, with smooth and bare lateral sides and pubescent metascutellum; metascutellum with three short longitudinal keels, median keel the highest. Propodeum 0.54 times as long as wide, almost bare medially and densely pubescent laterally, median propodeal keel simple; posterior margin of propodeum without any projections (Fig. 81). Side of propodeum entirely pubescent, with several longitudinal keels. Legs slender.

Wing venation. Fore wing with distinct costal, subcostal and basal veins; radial cell open; distance from marginal vein to basal vein equal to marginal vein length; stigma vein as long as radial vein and slightly longer than postmarginal vein. Poststigmal and cubital veins nebulous.

Metasoma. Petiole weakly broadened posteriorly, as long as wide, with shallow striation, bare dorsally and pubescent ventrally. T2 anteriorly bare, with short striation, median groove the longest (Fig. 81); posterior part of $\mathrm{T} 2$ covered with scattered long setae; T3-T6 narrow, with few setae; T7 and T8 elongate, strongly compressed laterally, weakly setose. S2 with short grooves at base, entirely pubescent with semirecumbent setae anteriorly and recumbent setae posteriorly; S3-S5 narrow, entirely pubescent; $\mathrm{S} 6$ distinctly elongate and compressed, shortly pubescent.

Male. Body length $2.5-3.6 \mathrm{~mm}$. Similar to female except following characters: antenna filiform, longer than body length; antennomeres cylindrical, covered by uniform semi-erect pubescent; A1 more stout, about 0.5 times as long as head width; A3 with shallow emargination and keel extending to $0.30-0.37$ of A3 length (Fig. 84); ratios of length to width of antennomeres shown on Fig. 85; petiole elongate 0.7-0.8 times as wide as long; T7 transverse, not compressed; S6-S7 narrow, transverse; T8 and S8 subtriangular, rounded apically.

VARIATION. Female. Body length 2.5-3.8. Forewings as long as body length to distinctly shorter.

DIAGNOSIS. This new species can be distinguished from all other Psilomma species by features given in the key (couples 1 and 2).

DISTRIBUTION. Russia (Far East), Japan (Honshu).

ETYMOLOGY. The name of this species is an arbitrary euphonious combination of letters, with no special meaning.

Psilomma dubia Kieffer, 1908

Figs 86-93

Psilomma dubia Kieffer, 1908: 426.

MATERIAL. Estonia: Suru Vill., 59.2650 N, 25.4300 E, 11.VII 2016, 1 ô, P.

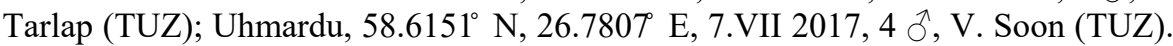
Ukraine: Zakarpatska Prov., Rakhiv City, 10.VIII 1989, 3 O, A. Kotenko (ZISP). Russia: Kaliningradskaya oblast: Kurshskaya Kosa (= Curonian Spit) National Park, $55^{\circ} 09^{\prime} 16.83^{\prime \prime} \mathrm{N}, 20^{\circ} 51^{\prime 2} 27.03 "$ E, Rybachiy, 24.VII-4.VIII 2006, 1 ○े, V. Kolyada 
(ZMUM); Novgorodskaya oblasty: Pestovo Distr., Tychkino Vill., 1-3.VIII 2002, 1 , , V. Tobias (ZISP); Moskovskaya oblast: Moscow City, Bitsa Park, 22.VII 1993, 1 §ै, V. Kolyada (ZMUM); Kirovskaya oblast: Bolsheromanovo, 3-17.VIII 1994, 5 o, 12 ふै, V. Kolyada (ZMUM); Altaisky krai: Tigirek Vill., 5.VII 2005, 1 , A. Reshikov (ZISP).
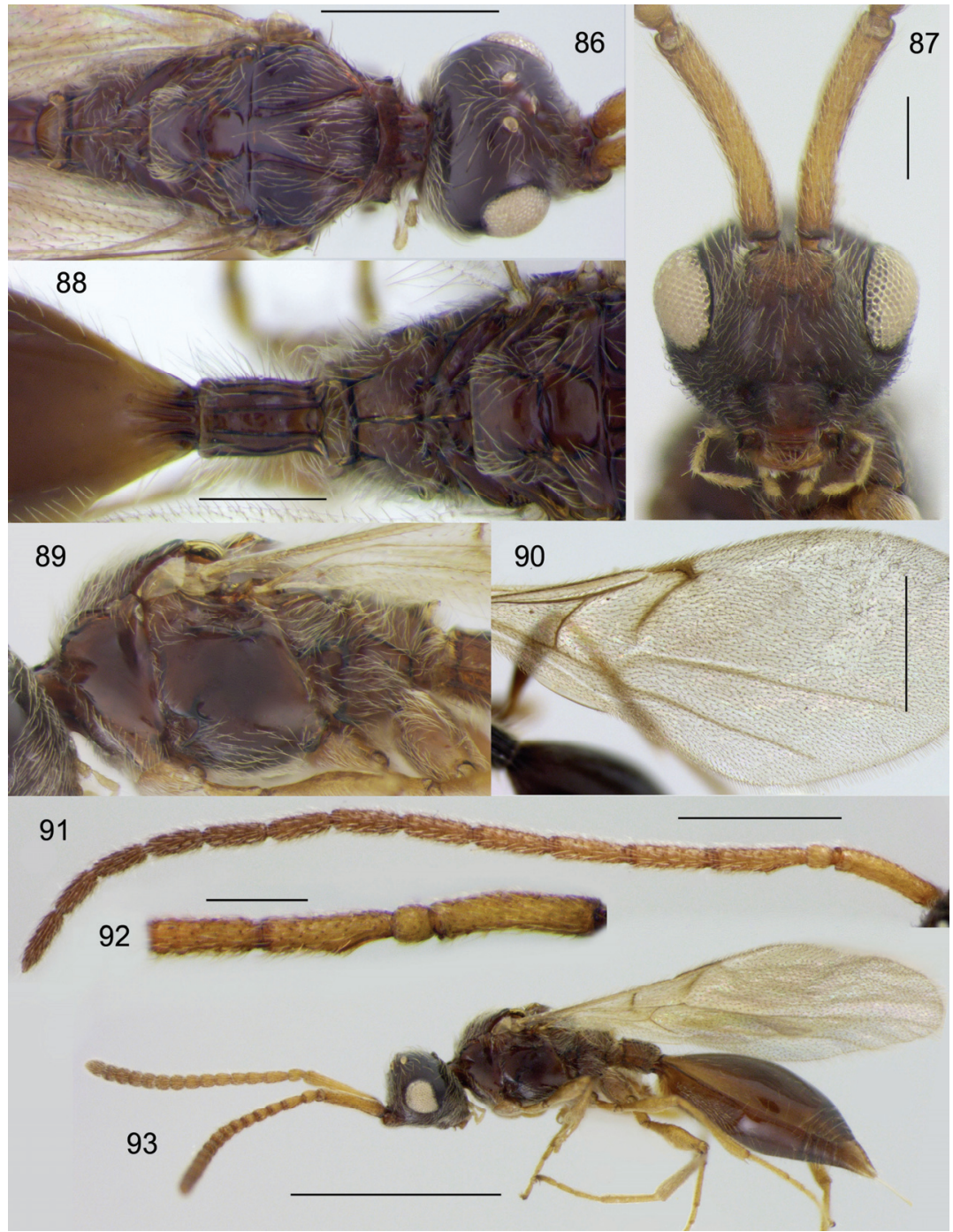

Figs 86-93. Psilomma dubia, $q$ (86-90, 93) and $\widehat{\partial}(91,92): 86$ - head and mesosoma, dorsal view; 87 - face; 88 - mesosoma and base of metasoma, dorsal view; 89 - mesosoma, lateral view; 90 - forewing venation; 91 - antenna; 92 - antenna, proximal part; 93 - habitus, lateral view. Scale bar: $93-1 \mathrm{~mm} ; 86,90,91-0.5 \mathrm{~mm} ; 87,88,92-0.2 \mathrm{~mm}$. 
VARIATION. Marginalis slightly shorter to slightly longer than distance from marginal vein to basal vein. Female. Body length 3.0-3.5 mm. Male. Body length 2.7-3.4 mm.

DISTRIBUTION. Ireland, United Kingdom, France, Sweden, Czech Republic, Poland, *Estonia, *Ukraine, *Russia (European part, Western Siberia), South Korea.

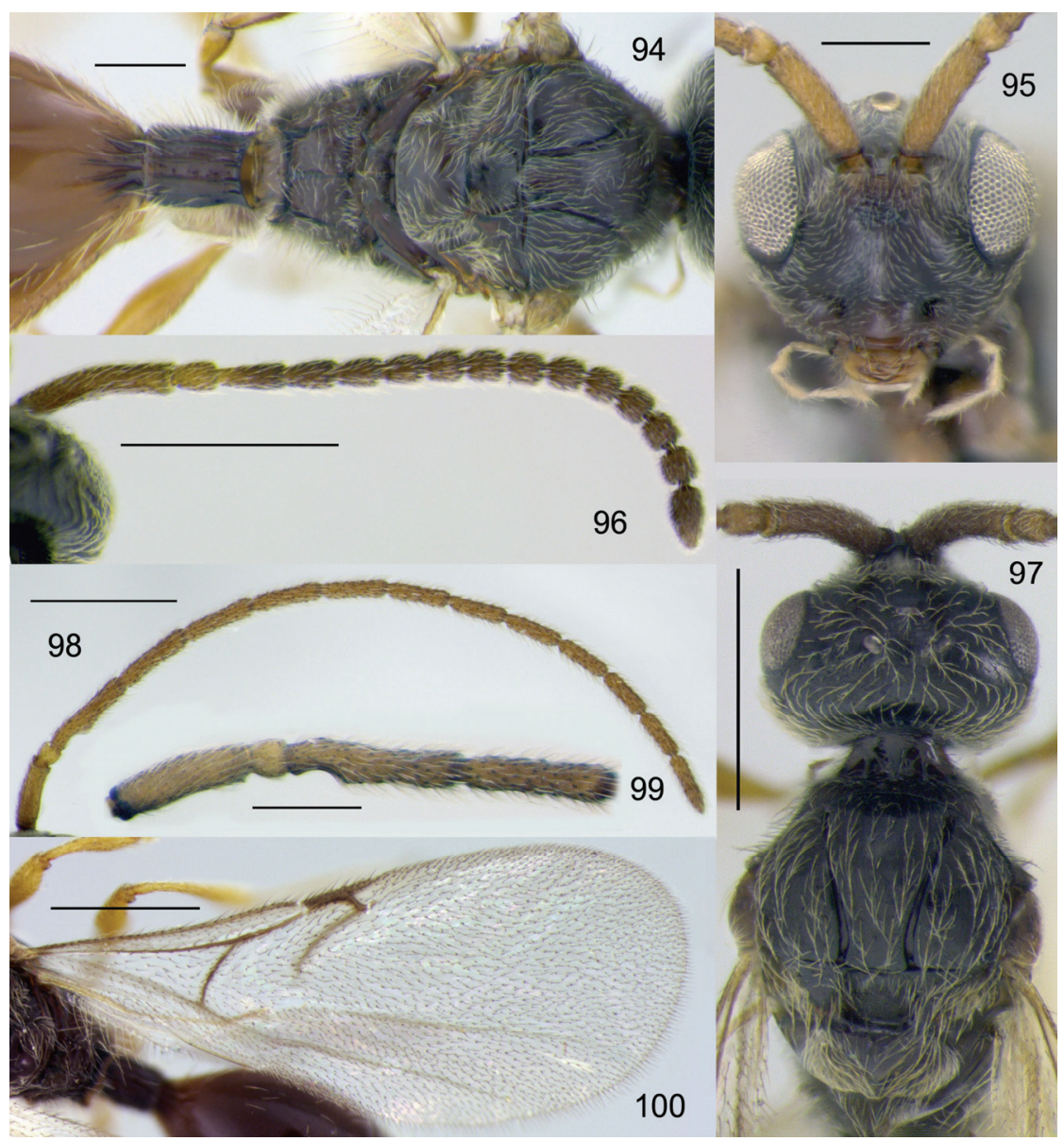

Figs 94-100. Psilomma fusciscapis, + (94-97, 100) and $\widehat{\partial}(98,99): 94$ - mesosoma and metasoma, dorsal view; 95 - face; 96, 98 - antenna; 97 - head and mesosoma, dorsal view; 99 - antenna, proximal part; 100 - forewing venation. Scale bar: 96-98, $100-0.5 \mathrm{~mm}$; 94 , $95,99-0.2 \mathrm{~mm}$.

\section{Psilomma fusciscapis Förster, 1861}

Figs 94-100

Psilomma fusciscapis Förster, 1861: 43. 
MATERIAL. Russia: Kaliningradskaya oblast: Kurshskaya Kosa (= Curonian Spit) National Park, 55 09'16.83" N, 2051'27.03" E, Rybachiy, 24.VII-4.VIII 2006, 12 §, V. Kolyada (ZMUM); Krasnodarsky krai: Sochi-Lazarevskoe, 20-24.V 1982 and 23-28.V 1974, 2 ô, V. Tobias (ZISP). Azerbaijan: Lankaran, 3-7.V 1971, 1 ๙̃, V. Tobias (ZISP).

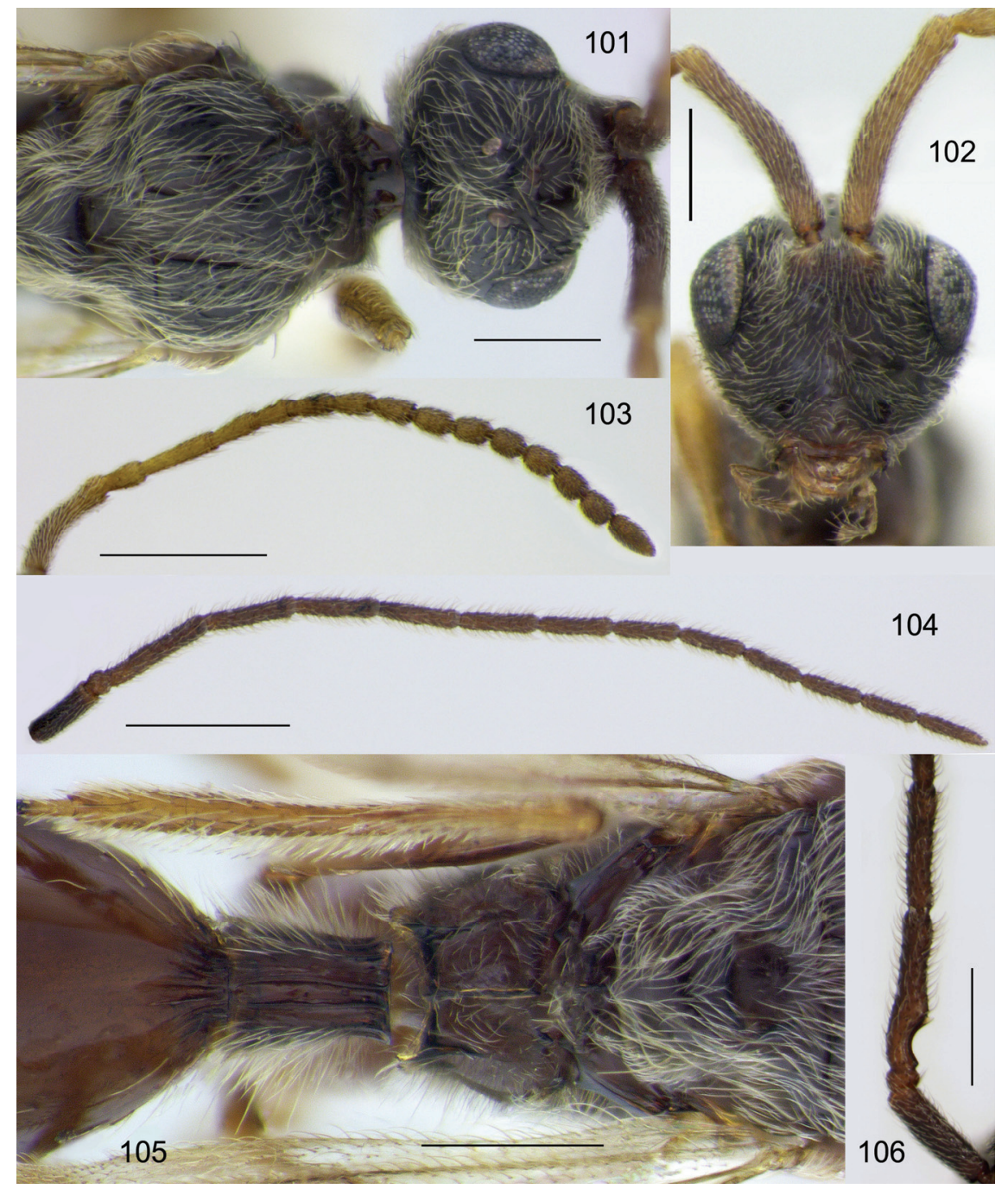

Figs 101-106. Psilomma fuscicornis, + (101-103, 105) and $\delta(104,106): 101-$ head and mesosoma, dorsal view; 102 - face; 103, 104 - antenna; 105 - mesosoma and base of metasoma, dorsal view; 106 - antenna, proximal part. Scale bar: 103, $104-0.5 \mathrm{~mm}$; 101, $102,105,106-0.2 \mathrm{~mm}$. 
VARIATION. Male. Body length 2.6-3.6. A3 with keel extending to 0.33-0.37 of A3 length. Forewing venation very variable: marginal vein $0.17-0.25$ times as wide as long and $0.64-0.87$ times as long as distance from marginal vein to basal vein; stigmal vein as long as width of marginal vein to distinctly longer. Petiole 0.5-0.7 times as wide as long.

DISTRIBUTION. Sweden, Czech Republic, Austria, Poland, Hungary, *Russia (European part), *Azerbaijan.

Psilomma fuscicornis Kieffer, 1908

Figs 101-106

Psilomma crassicornis var. fuscicornis Kieffer, 1908: 426.

Psilomma fuscicornis: Macek, 1990: 338.

MATERIAL. Ukraine: vicinity of Kiev City, 4.VII 1984, 1 $\widehat{\jmath}$, A. Kotenko; Poltava Prov., Myrhorod Distr., 31.VIII 1985, 1 §, A. Kotenko. Russia: Primorsky krai: Furmanovo Vill., 15.VI 1972, 1 ๙, A. Rasnitsyn. Georgia: Stepantsminda [=Kezbegi], 14-18.VIII 1982, 1 ふै, Dbar. Kazakhstan: Karaganda Prov., Karkaralinskiye Mts, 15.VI 1957, 2 $\widehat{\lambda}$, V. Tobias. Turkmenistan: $23 \mathrm{~km} \mathrm{SW}$ of Jebel, 22.V 1979, 1 , V. Rikhter. All in ZISP.

VARIATION. Marginalis slightly to distinctly shorter than distance from marginal vein to basal vein. Female: body length 2.6-2.8 mm. Male: body length 2.0-2.5 mm; A3 as long as A1 to slightly shorter.

DISTRIBUTION. Ireland, England, France, Switzerland, Czech Republic, *Ukraine, *Russia (Far East), *Georgia, *Kazakhstan, *Turkmenistan.

\section{ACKNOWLEDGMENTS}

This study was supported by the Russian Foundation for Basic Research (project No 19-04-00027).

\section{REFERENCES}

Ashmead, W.H. 1893. A monograph of the North American Proctotrypidae. Bulletin of the United States National Museum, 45, 472 p.

Buhl, P.N. 1992. A new species of Polypeza (Hym., Diapriidae, Belytinae) from Denmark. Entomologists Monthly Magazine, 128: 79-80.

Chemyreva, V.G. 2021. Review of the genus Opazon Haliday (Diapriidae, Belytinae) in the fauna of Russia. Russian Entomological Journal, 30(1): 78-83.

Chemyreva, V.G. \& Kolyada, V.A. 2019. Review of the Pantolyta genus (Hymenoptera: Diapriidae: Pantolytini) from Russia, with description of a new species. Zoosystematica Rossica, 28(1): 163-176.

Chemyreva, V.G. \& Kolyada, V.A. 2020. Review of the genus Synacra Foerster (Hymenoptera, Diapriidae: Pantolytini) in the Palaearctic region, with description of new species. Entomological Review, [2019], 99(9): 1339-1358. 
Chemyreva, V.G. \& Kolyada, V.A. 2021. Taxonomy of the genera Acropiesta Förster, Anommatium Förster and Pantolyta Förster (Diapriidae: Belytinae) with review of the species occurring in Russia. Zoosystematica Rossica, 30(1): 137-162.

Förster, A. 1856. Hymenopterologische Studien. II. Heft. Chalcidiae und Proctotrupii. Aachen: Ernst ter Meer. 152 pp.

Förster, A. 1861. Ein Tag in den Hoch Alpen. Programm der Realschule zu Aachen fur das Schuljahr 1860/61. Aachen. 44 pp.

Haliday, A.H. 1857. Note on a peculiar form of the ovaries observed in a hymenopterous insect, constituting a new genus and species of the family Diapriidae. Natural History Review, 4: 166-174.

Kieffer, J.-J. 1908. Proctotrypidae (suite). In: André E. (Ed.). Species des Hyménoptères d'Europe et d'Algérie, 10: 289-448. Hermann \& Fils, Paris.

Kim, C.-J. \& Lee, J.-W. 2016a. First record of the genus Psilomma Förster (Hymenoptera: Diapriidae) from the Eastern Palaearctic Region. Korean Journal of Applied Entomology, 55: 293-296.

Kim, C.-J. \& Lee, J.-W. 2016b. First record of the monotypic genus Acanopsilus Kieffer, 1908 (Hymenoptera: Diaprioidea: Diapriidae) from the Eastern Palaearctic region. Biodiversity Data Journal, 4: e9572.

Kozlov, M.A. 1978. Fam. Diapriidae. P. 548-608. In: Medvedev, G.S. (ed.), [Keys to insects of the European part of USSR. Vol. 2, Pt 2.]. Nauka, Leningrad. [In Russian]

Macek, J. 1989. Studies on Diapriidae (Hymenoptera, Proctotrupoidea). Part 1. Taxonomic remarks on the subfamily Belytinae with particular reference to the tribus Pantolytini. Annales zoologici, 42(17): 353-362.

Macek, J. 1990. Revision of European Psilommina (Hymenoptera, Diapriidae) 1. Psilomma and Acanosema complex. Acta entomologica musei nationalis Pragae, 43: 335-360.

Macek, J. 1993. Revision of Holarctic Polypeza (Hymenoptera, Diapriidae). Folia Heyrovskyana, 1(2): 19-24.

Masner, L. \& García, J.L. 2002. The genera of Diapriinae (Hymenoptera: Diapriidae) in the New World. Bulletin of the American Museum of Natural History, 268: 1-138.

Naumann, J. 1982. Systematics of Australian Ambositrinae (Hymenoptera, Diapriidae), with synopsis on non-Australian genera of the subfamily. Australian Journal of Zoology, 85: $1-239$.

Nixon, G.E.J. 1957. Hymenoptera, Diapriidae, subfamily Belytinae. Handbooks for Identification of British Insects, 8(3diii): 1-107.

Thomson, C. G. 1858. Sverges Proctotruper. IV. Tribus Belytini. Öfversigt af Kongliga Svenska Vetenskaps-Akademiens Förhandlingar, 15: 155-180.

Yoder, M.J. 2004. Revision of the north American species of the genus Entomacis (Hymenoptera: Diapriidae). The Canadian Entomologist, 136: 323-405.

Yoder, M.J., Mikó, I., Seltmann, K.C., Bertone, M.A. \& Deans, A.R. 2010. A gross anatomy ontology for Hymenoptera. PLoS ONE, 5: e15991. 